AperTO - Archivio Istituzionale Open Access dell'Università di Torino

\title{
European Unemployment Revisited: Shocks, Institutions, Integration
}

\section{This is the author's manuscript}

Original Citation:

\section{Availability:}

This version is available http://hdl.handle.net/2318/1643256

since 2017-09-06T11:29:45Z

Published version:

DOI:10.1016/j.rie.2017.06.002

Terms of use:

Open Access

Anyone can freely access the full text of works made available as "Open Access". Works made available under a Creative Commons license can be used according to the terms and conditions of said license. Use of all other works requires consent of the right holder (author or publisher) if not exempted from copyright protection by the applicable law. 


\title{
European Unemployment Revisited: Shocks, Institutions, Integration
}

\author{
Giuseppe Bertola * \\ Forthcoming Research in Economics 2017
}

\begin{abstract}
This paper painstakingly restores a vintage empirical model that relates unemployment to shocks and institutions, and proceeds to run it on recent data featuring dramatic shocks and controversial institutional change. The original specification fails to fit these data. Theoretical insights and the results of suitably modified regressions suggest that the capital flow and reforms implications of international economic integration are crucial for interpreting twists and turns of unemployment rates in Europe and elsewhere.
\end{abstract}

* Università di Torino, CEPR, CESifo. Thanks for comments to the discussant Juan Francisco Jimeno, to Olivier Blanchard, and to other 2016 Jacques Polak Annual Research Conference participants. Any errors and views are those of the author and must not be attributed to any other person or institution. 


\section{Introduction}

Unemployment is a vast issue, approached in this paper from the particular perspective originally proposed by Blanchard and Wolfers (2000, henceforth BW).

Figure 1 displays unemployment rate paths over 5-year periods since 1960 for the countries in the sample studied by BW. The sample stops with the 2010-14, as later observations would belong to a currently incomplete period for which institutional information is not yet available. The data are plotted separately and on different scales for current euro area members (Austria, Belgium, Finland, France, Germany, Ireland, Italy, Netherlands, Portugal, Spain), other European countries (Denmark, Norway, Sweden, Switzerland, United Kingdom), and non-European countries (Australia, Canada, Japan, New Zealand, United States). Separating these groups of countries improves the graphs' legibility and highlights the empirical motivation of BW's approach. In the first portion of the currently available time span, unemployment rates trended upwards in European (especially Continental) countries, but moved cyclically along fairly stable and ultimately lower levels in other (especially "Anglo-Saxon") countries. To interpret that experience BW assessed the empirical fit of a model that confronts institutionally different countries with common shocks, and explored the empirical relevance of three country-specific macroeconomic shock variables and of their interactions with labor market institutions.

At just about the time when BW was being written the data began to look different. The previous persistence or even hysteresis (Blanchard and Summers, 1986) of unemployment came to an end in Europe. Unemployment rates began to decline and converge during the run up to and early phases of Economic and Monetary Union, then surged and diverged as the Great Recession and the European debt crisis hit. These data are very different in crucial respects from those analyzed by BW and their references to the European Unemployment strand of 1990s literature. The data sets used by Nickell, Nunziata, and Ochel (2005), Bertola, Blau, and Kahn (2002), Bassanini and Duval (2006) and other contributions that extending and finesse the BW approach also stop very soon after 2000.

This paper revisits the BW empirical approach and applies it to recent data featuring controversial labor market reforms and uncommon (unprecedented, and with different implications for different countries) macroeconomic events. The empirical exercise offers an opportunity to appreciate and discuss conceptual and methodological aspects of BW, of the related work in Blanchard 
(1997, 2006) and in those papers' references, and more generally of macro-level, policy-oriented empirical work on labor market institutions and outcomes. Country panel regressions are not as fashionable as they used to be. Because plausibly relevant variables and mechanisms are much more numerous than available observations, empirical models that seek aggregate evidence unavoidably oversimplify reality. The results can be confusing and misleading (Baccaro and Rei, 2007). The statistical significance of interesting coefficients is sometimes driven by inclusion or omission of a single country's observations, and this and other regression specification choices can be suspicious just because the results confirm specific theoretical priors. Empirical work on limited data cannot always provide robust insights. But descriptive regressions, like paintings, can portray reality in an interesting way, and crisply outline sensible theoretical mechanisms. The BW empirical approach established that institutional heterogeneity does not fully explain country-level unemployment variation. The present paper suggests that a next step, focused on international spillovers triggered by financial integration, may help interpret sharp unemployment swings within Europe, and shed some light on the determinants of the institutions that in turn determine unemployment.

Section 2 updates the BW regressions and finds that their original specification does not fit recent experience well. Section 3 revisits the structural underpinnings of the BW regressions, which treated institutions as exogenous and adopted a closed-economy perspective, and outlines subsequent theoretical progress. In theory and reality international capital mobility and politico-economic tensions are plausible and increasingly important drivers of labor market shocks and institutional reforms. This suggests that accounting for variation of international economic integration can potentially mend the empirical problems encountered by closed-economy regression specifications in the more recent portion of the updated sample. Section 4 runs regressions that extend BW's specification to include current account information, and detect a significant and correctly signed association between unemployment and current account variation. This evidence, while as descriptive as the original results, is remarkably consistent with plausible theoretical explanations of those results' recent disappearance. Exploratory regressions support this interpretation detecting a sensible association of current account variation and institutional reforms, which in turn account for a significant portion of unemployment variation. Section 5 concludes with a brief summary and discussion of policy implications. 


\section{Restoration and update}

In the following expressions $U_{c t}$ is the unemployment rate in country $c$ and period $t$. Explanatory variables $I_{i c t}$ and $S_{j c t}$ are institutions (indexed by $i$ ) and shocks (indexed by $j$ ) in country $c$ and period $t$. All are measured as deviations from their mean within each regression's sample, which is a slightly unbalanced panel if data are not available (see the Data Appendix for definitions, sources, and plots of available observations by variable, country, and period). The regressions may also include country fixed effects $c_{c}$ and period fixed effects $t_{t}$.

\subsection{Institutions and time}

Table 1 considers a regression that related unemployment rates to period dummies, allowing this time effect to depend on time-invariant institutional characteristics of each country, and country fixed effects: ${ }^{1}$

$$
U_{c t}=\left(1+\sum_{i} \beta_{i} I_{i c}\right) t_{t}+c_{c}+\varepsilon_{c t} .
$$

The first column replicates BW. The regression asks the data whether institutions matter differently at different times. This was a natural question when observing unemployment fanning out between the 1970s and the 1990s. The answer is that observable institutional characteristics do significantly influence the amplitude of unemployment's variation over time. Institutions are measured in a way that implies positive interaction coefficients if generous unemployment insurance, strong employment protection, large tax wedges, and pervasive unionization increase the persistence of unemployment through cycles that would generate unemployment fluctuations in less regulated economies, while active labor market policies and wage-setting coordination (both taken with negative sign) reduce unemployment persistence. The BW sample's data conform to expectations in that most interaction effects are significantly larger than zero.

The second column uses all currently available unemployment rates shown in Figure 1. For the 20 countries considered in BW the sample includes one-and-a-half as many 5-year periods, and five degrees of freedom are consumed by the new period effects. Not surprisingly, some of the institutional indicators measured in the late 1980s and early 1990s lose significance: these are active labor market

\footnotetext{
${ }^{1}$ The current Stata syntax for this equation is

$\$ D E P V=(\{i: \$ I N S T\}) *(\{$ tef:_Iperiod_* $\})+\left\{\right.$ tef:_Iperiod_*\} $+\left\{c:_{-}\right.$Icn_* $\}$

where global \$DEPV contains the name of an unemployment series and \$INST those of institutional variables.
} 
policy, which in BW's data (drawn from Nickell, 1997) was measured in a rather elaborate way that would be difficult to update and is particularly subject to data-mining suspicions voiced by BW; and the tax wedge and union density, which in the updated series (see the Data Appendix) have both changed rather differently across countries. Other indicators do remain significantly related to unemployment variation even as it ceases to trend upwards in column 2, which runs the regression on the complete updated sample, and column 3, which uses only its more recent portion.

The regressions in Table 2 relate unemployment levels to time-invariant institutions rather than unrestricted country dummies,

$$
U_{c t}=\left(1+\sum_{i} \beta_{i} I_{i c}\right) t_{t}+\sum_{i} \gamma_{i} I_{i c}+\varepsilon_{c t} .
$$

As in the original BW sample used in column 1, so in the updated and more recent samples of columns 2 and 3 the interaction coefficients are somewhat weaker than those estimated in Table 1.

Table 3 reports interaction coefficient estimates from the nonlinear regression ${ }^{2}$

$$
U_{c t}=\left(1+\sum_{i} \beta_{i} I_{i c t}\right) \gamma t_{t}+c_{c}+\varepsilon_{c t},
$$

which lets period effects interact with time-varying indicators of country-specific labor market institutions. The results were not particularly strong in the original BW regressions replicated in columns 1 and 2. The remaining columns of the Table run the regression on the complete current sample, using some time-invariant BW institutional indicators and updated indicators of unemployment insurance generosity, employment protection, labor taxation, and union density. These, documented and shown in the Data Appendix, capture quantitatively some familiar trends (such as the secular decline of unionization) and swings (such as the US increase and German decline of unemployment insurance generosity in the 2000s). Regardless of whether only the originally available time-varying indicators are updated (in column 3), and of whether time-invariant indicators of active labor policy, union coverage, and wage setting coordination are included (in column 4) or excluded (in column 5), unemployment insurance generosity and labor taxation have significantly positive period-interaction coefficients, while employment protection's interaction coefficient is insignificant. Union density's interaction is mildly and negatively significant only when indicators of wage-bargaining coverage and coordination are omitted.

\footnotetext{
${ }^{2}$ In Stata,

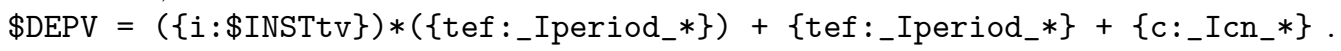




\section{$2.2 \quad$ Institutions and shocks}

Consider next the role in the more recent period of the country-specific labor market shocks defined by BW, and updated here as discussed in detail by the Data Appendix. These are the rate of total factor productivity (TFP) growth, which is negatively associated with unemployment if real wages fail to adjust to it, and measured with a negative sign to imply a positive expected coefficient; the real interest rate, which may be relevant through capital accumulation and in a variety of other ways (Phelps and Zoega, 1998); and a dynamically adjusted log labor share which, under conditions discussed in Blanchard (1997) and in Section 3 below, can capture the unemployment implications of temporarily misaligned real wages.

Figure 2 plots these indicators, again separately on different scales for three groups of countries. After the end of the BW sample, TFP ceases to slow down and fluctuates widely in the run-up to the great recession and in its aftermath. The real rate, after a strong increase in the 1980s, declines sharply from the mid 1990s to the current "secular stagnation" phase, on time paths that are very similar across countries. The labor demand shock turns positive in European countries only after the end of the BW sample, and continues its previous upward trend in the control group of non-European countries.

Table 4 reports the slope coefficients of a linear regression of unemployment on these shocks, country fixed effects, and a $P_{c t}$ dummy that equals unity only in Portugal for the period, coinciding with the country's revolution, when for that country the OECD Business Sector Database labor share data behave in a very peculiar way: ${ }^{3}$

$$
U_{c t}=\sum_{j} \gamma_{i} S_{j c t}+\pi P_{c t}+c_{c}+\varepsilon_{c t}
$$

The behavior of shocks is sufficiently diverse to disentangle their separate contributions to unemployment variation. All three have positive coefficients in column 1, which uses the original BW data and sample. The coefficients are still positive and significant in column 2, which uses the updated data set. Shockingly, however, the coefficient of TFP growth has the wrong sign when in column 3 the early portion of the sample is dropped.

Table 5 reports the shock and institution coefficients of a regression that allows institutions to

\footnotetext{
${ }^{3}$ BW's Table 4 did not control for this and estimated a less significantly positive labor demand shock coefficient than in the present paper's Table 4. These and other empirical results are only mildly affected by omitting the dummy, or indeed dropping all Portuguese observations.
} 
matter for the unemployment impact of shocks: ${ }^{4}$

$$
U_{c t}=\left(\sum_{j} \gamma_{j} S_{j c t}+\pi P_{c t}\right)\left(1+\sum_{i} \beta_{i} I_{i c}\right)+c_{c}+\varepsilon_{c t} .
$$

The fit is very good in the original BW results of column 1, not much worse in the updated extended sample of column 2 and in the recent sample of column 3. As shown in Figure 3, the estimated empirical relationship captures not only unemployment increases between the 1970s and the 1990s, but also the heterogenous and asymmetric developments of the following decades, when European countries took turns in leading unemployment swings. In the recent past, however, the fit and predictive power of these regressions is mostly due to shocks, insignificantly shaped by time-invariant institutions, and relies on a strangely signed TFP growth coefficient.

The perverse association between unemployment and TFP growth in the periods when the latter did not simply trend downwards, but began to fluctuate and diverge, suggests that the BW empirical approach does not appropriately account for something that has become important only since the 1990s. Labor market reforms are a potentially relevant source of variation. Following BW, Table 6 inserts time-varying institutional indicators in regression (5). The results do not add much to previous ones. In the BW regressions replicated in columns 1 and 2 most interaction effects are insignificant and hard to interpret, and they remain so when using the complete updated sample in column 3. Results for the most recent sample, not reported, are even weaker and harder to interpret: the overall fit is similar to that of the time-invariant institutions regressions of Table 5 , and the shock coefficients are not positive.

\section{Theory}

The results of the previous section's restoration and update exercise qualify the BW insights: recent data appear to be beyond reach of that paper's empirical approach. This is useful food for thought, and this section proceeds to discuss how the structural mechanisms that generate the data described by the BW regressions may, in the light of older and newer theory, be influenced by phenomena that became more relevant since the 1990s.

To characterize the theoretical basis of regressions that relate observed unemployment to non-

\footnotetext{
${ }^{4}$ In Stata:

$\$ D E P V=(\{\mathrm{s}: \$$ SHCK $\}+\{$ PORTDUM $\} *$ portrev $\left.) *(1+\{i: \$ I N S T\})+\left\{c: \_I c n_{-} *\right\}\right)$.
} 
linear functions of institutions and shocks, let each country's per capita domestic production be $y=\left(k_{d}\right)^{\gamma}(a l)^{(1-\gamma)}$, where $l$ indexes employment and $k_{d}$ denotes the stock of capital. As discussed below and in Blanchard (1997) it can be useful to relax the constant-elasticity assumption, which however is very convenient also on the supply side of the labor market: if in income terms the opportunity cost of employment $l$ has the constant-elasticity functional form $(l)^{1+\beta} /(1+\beta)$, then the marginal cost $l^{\beta}$ of labor supply equals

$$
w=(1-\gamma)\left(k_{d}\right)^{\gamma}(a)^{1-\gamma} l^{-\gamma}
$$

when unemployment is zero and the wage $w$ corresponds to labor's marginal productivity..

\subsection{Institutions}

To rationalize positive unemployment in the absence of shocks let market institutions be chosen, as in Bertola (2016), so as to maximize the welfare of an individual who earns the per-capita labor income and a proportion $x<1$ of other per capita income. At given $k_{d}$ and $a^{1-\gamma}$, the relevant first-order condition is ${ }^{5}$

$$
(1+\gamma(x-1)) w=l^{\beta}
$$

If $x=1$, then $w=l^{\beta}$ : the welfare of the economy's average individual is maximized at zero unemployment. Just like unions that disregarding employers' profits maximize the wage bill, however, so individuals who earn only a portion of the economy's non-labor income find it optimal to decrease employment. If $x<1$ (the political majority is less wealthy than average), condition (7) drives a proportional wedge between the market wage and the non-market value of time and reduces employment below the market-clearing level. The median voter is capital-poorer than the average individual if wealth is more unequally distributed than labor income. In democratic countries, individuals who earn less than the average non-labor income do support employment taxes and non-employment subsidies, legal or collectively bargained minimum wages, limits on weekly work hours, minimum annual holidays, and age-related employability rules (Bertola, 2016).

Employment rates also depend on educational policies and demographics (Bertola, Blau, and Kahn, 2007), which are theoretically and empirically relevant also for unemployment (Bertola, Blau, and Kahn 2002). To focus here on the unemployment implications of (7), suppose that institutions

\footnotetext{
${ }^{5}$ To see this add per capita labor income $w l=(1-\gamma) y$ to other income $x \gamma y$, differentiate with respect to $l$ using $d y / d l=w$, and equate the resulting expression to $l^{\beta}$.
} 
keep wages are above the market-clearing level, and note that the welfare of a decisive individual who earns a fraction $x<1$ of average non-labor income is maximized at unemployment ${ }^{6}$

$$
u \approx \log l_{s}-\log l_{d}=\frac{\gamma}{\beta}(1-x)
$$

This simple expression clearly oversimplifies a reality where there is frictional unemployment even in laissez faire and labor market institutions also address incomplete information and risk issues. In models where wages are determined by decentralized match-level bargains, full employment is unreachable if jobs are subject to shocks, matching them to unemployed workers requires costly vacancy-posting and search activities, and wages and employment are determined by job creation and wage determination schedules that cross at a point where unemployment is positive (Mortensen and Pissarides 1994). The insight illustrated by (8), however, is robust to such extensions. Unemployment can deviate persistently from its laissez faire level as an intentional side effect of policies meant to benefit relatively poor individuals, implemented in each country in ways that depend on the distribution of political decision power as well as on uninsurable shock histories.

The politico-economic mechanism underlying (8) may help interpret country-level relationships between unemployment and the institutions that are empirically related to it. In its simplicity, however, that expression illustrates how complicated it can be, even treating each country as an isolated experimental unit, to interpret the empirical variation of unemployment. Its intentional component may reflect different values of the decisive agent's labor intensity and political power $(x$ in the model), or of the elasticities $(\gamma$ and $\beta$ ) that shape the welfare implications of employment. Depending on administrative traditions, employment may be shaped by contributions and subsidies that leave measured unemployment constant, rather than by wage-setting constraints.

In empirical work, all this might be constant over time and absorbed by the country fixed effects included in the BW regressions. But variation over time of a country's institutions, driven by political and structural forces, influences unemployment directly and not just through interactions with period effects or observable shocks. The exclusion of institutional main effects from the regressions reported in Tables 3 and 6 was appropriate when trying to interpret different unemployment dynamics in countries with stable institutions and similar exposure to largely common shocks. The stronger time

\footnotetext{
${ }^{6}$ Inserting (6) in (7) establishes that when $x \neq 1$ the log level of optimal employment is lower by $\gamma(1-x) /(\beta+\gamma)$ relative to the laissez faire zero unemployment level. The $\log$ wage is $\gamma^{2}(1-x) /(\beta+\gamma)$ higher along the labor demand schedule, log labor supply grows by $\left(\gamma^{2} / \beta\right)(1-x) /(\beta+\gamma)$, and (8) follows.
} 
variation of institutions since the 1990s, when reforms began to be discussed and implemented at different paces in different countries, is not necessarily absorbed by country and period effects.

\subsection{Shocks}

To see how shocks can be relevant to observed variation of unemployment across countries and over time, it is simplest to suppose that real wage are preset and, along with labor force participation on an unchanged supply schedule, do not react to labor demand variation. (Real wages vary, with more complicated but qualitatively similar implications, if nominal wages are preset and inflation is unexpected.) If the wage is preset at $w$ expecting $a=a_{0}$, at given $k_{d}$ employment and unemployment deviate from their intended level if in realization $a=a_{1} \neq a_{0}$.

Combining $\log l=(\log (1-\gamma)+(1-\gamma) \log (a)-\log w) / \gamma$ from (6) and (8), realized unemployment

$$
\tilde{u} \approx \frac{\gamma}{\beta}(1-x)+\frac{1-\gamma}{\gamma}\left(\log \left(a_{0}\right)-\log \left(a_{1}\right)\right)
$$

varies across countries and periods for two related but distinct reasons. One is that structural features and institutions steer the wage away from the market-clearing level, as illustrated by (8) and captured by the first term on the right-hand side of (9). The other is that, at preset wages, forecast errors move employment away from the level that the politico-economic mechanism would choose after observing realized labor demand. The two mechanisms are related in that wages are naturally preset if they are bargained collectively, and negotiation outcomes giving more weight to labor income than to other income ( $x<1$ in terms of this simple formal framework) target a positive level of unemployment that may ex post be reduced or increased by labor demand shocks.

Several theoretical refinements are potentially relevant. If wage-setting and other relevant institutions only slowly adjust to changes in the relevant parameters, such as the $\gamma$ and $\beta$ elasticities of this simple model, similar shocks can have different employment implications across countries that differ in those respects (Blanchard and Philippon 2004). And if decentralized wages are bargained within a range of values that makes continued employment privately preferable to costly separation and search may remain constant when shocks vary the boundaries of that range (Hall 2005), they need not decline along with labor demand and can remain higher in recessions than would be justified by search and matching (Michaillat 2012). In that situation, the unemployed are rationed out of jobs not by legal or contractual constraints but by their inability, in a decentralized bargaining 
framework, to bid down the wage of employed workers.

In terms of empirically observable variables, the identity $l_{d}=(w l / y) y / w$ and $u \approx \beta \log w-\log l_{d}$ yield unemployment $u=(1+\beta) \log w-\log (w l / y)-\log y$, which deviates from zero if $l \neq \beta \log w$. If employment is on a constant-elasticity labor demand, then $w l / y=(1-\gamma)$ and, at given $w$, a constant $\gamma$ implies a unitary coefficient for output growth as an explanatory variable of unemployment changes. In the data, that coefficient varies considerably across countries and periods (Bertola, 2015), and is much below unity (it was about one-half in Okun's original statement of his law).

One way to accommodate this is to allow the elasticity of labor demand, and the observed labor share, to vary over time. BW's empirical implementation of this idea, outlined and reproduced in the Data Appendix, constructs an empirical counterpart of the second right-hand side term of (9), using the observed labor share to proxy $\gamma$ and TFP growth estimates to measure changes of $a$.

Another way is to relax the assumption that employment is on labor demand, and that employment somewhat implausibly adjusts faster than wages. If marginal productivity $(1-\gamma) y / l$ exceeds the wage by a proportional amount $z w$ in a given time and period, then $(1-\gamma) y / l=(1+z) w$, and at constant $\gamma$ the labor share $w l / y=(1-\gamma) /(1+z)$ varies if $z$ does. Adjustment costs indeed insert time-varying wedges between labor's marginal revenue product and wage. When employment is growing the labor share falls short of $1-\gamma$, because $z>0$ : marginal productivity equals the current period's wage flow plus the annuity value, along the employers' optimal path, of current hiring costs and expected future firing costs. Conversely, when employment declines then $z<0$ and the observed labor share is larger than the technological elasticity. These effects are more pronounced when variation is perceived to be temporary (as explained for example in Bagliano and Bertola, 2007, chapter 3).

The BW regressions use the labor share as an indicator of labor demand changes at preset wages, supposing that the parameters governing its relationship to unemployment are constant across observations, or differ in ways captured by country effects and institutional indicators. In the original BW sample, the empirical role of labor share changes as determinants of unemployment is correctly signed, statistically significant, and distinct from that of TFP growth (which in the presence of $z$ wedge variation is, as conventionally estimated, a distorted version of $a$ variation). In recent data, however, variation of adjustment costs may require different specifications. 


\subsection{Capital and international integration}

When capital can flow to or from the rest of the world, then the a country's per capita wealth $k$ generally differs from the domestic stock $k_{d}$ used in production. If capital flows into the country, a larger $k_{d}$ increases labor demand

$$
l_{d}=\left(\frac{w}{(1-\gamma) a^{1-\gamma}}\right)^{-1 / \gamma} k_{d}
$$

and reduces observed unemployment at given wages. Tighter financial integration triggers capital inflows and shifts the labor demand schedule (10) upwards for a country with relatively scarce capital, and symmetrically reduces labor demand and increases unemployment at given wages for a capital-abundant country. Thus, the last term in (9) should account among shocks not only for TFP variation but also for the variation of $k_{d}$ that, at given $k$ (and given wages or institutions), may be induced by changes of capital mobility.

Bertola (2017) models the tightness of international integration supposing that the productivity of foreign-owned capital in domestic production is lower than that of national capital. ${ }^{7}$ In that setting, capital mobility also influences wage determination, not only along the country's labor supply schedule but also through the politico-economic mechanism that, as outlined above and summarized in the first term on the right-hand side of (9). Capital inflows are associated with stronger politicoeconomic incentives to reduce employment and increase unemployment. ${ }^{8}$ Intuitively, the political choice process only considers the interests of the country's nationals, so it is more inclined to reduce complementary capital's income when foreigners own a larger portion of its domestic stock. For a country that experiences capital outflows, theory has symmetric implications: employment declines at given institutions, and institutions change in ways that tend to increase employment and reduce unemployment.

\footnotetext{
${ }^{7}$ Formally, if $\nu \leq 1$ indexes the proportional productivity shortfall of a $\Delta$ amount of foreignowned capital then efective domestic capital is $k_{d}=k+\nu \Delta$ Solving for $\Delta$ the condition $\nu((k+\nu \Delta) /(a l))^{\gamma-1}=((K-\Delta)(A L))^{\gamma-1}$ of equal net capital productivity establishes that $a l /(k+\nu \Delta)=\left(a l+A L \nu^{-\frac{\gamma}{1-\gamma}}\right) /(k+K \nu)$.

${ }^{8}$ Using the factor intensity expressions in the previous footnote, the optimality condition for maximization with respect to $l$ of the welfare of a decisive agent who earns the per capita labor income and the unit return $r=\gamma y / k_{d}$ on a proportion $x$ of the country's average wealth is

$$
\left(1+\gamma\left(\frac{x k}{k+\nu K}-\frac{a l \nu^{\frac{\gamma}{1-\gamma}}}{a l \nu^{\frac{\gamma}{1-\gamma}}+A L}\right)\right) w=b l^{\beta},
$$
}

where the left-hand side is decreasing in $\nu$. 
The role of interest rates and TFP as an explanatory variable in the BW unemployment regressions was based on a theoretical perspective (Blanchard, 1996) that approximates each country's labor productivity around the steady state of its closed-economy capital accumulation path, and models temporary fluctuations (reflecting lagged or costly adjustment) around a perfectly elastic wage-employment relationship. Because international finance has developed strongly over the last few decades, capital flows may help explain the relatively poor recent performance of that approach.

\section{Back to the data}

The updated and extended data set of Section 2's replication exercise is disciplined by independent definitions and earlier use, and offers a suitable empirical setting for assessing the practical relevance of theoretical insights outlined in Section 3 and developed more fully in Bertola (2017) and its references.

This section aims to see whether the empirical difficulties of the BW approach in capturing recent unemployment developments can be remedied by attention to international financial integration's implications for labor market outcomes and distribution-motivated labor market institutions.

\subsection{Unemployment and capital flows}

Tighter financial integration lets international capital flows influence labor markets more strongly and quickly than closed-economy capital accumulation dynamics. The relative capital scarcity of countries need not be related to their position relative to their own conditional steady state, and slow savings-driven dynamics can be dwarfed by quick capital movements, as was the case in the initial phase of Europe's Economic and Monetary Union (Blanchard and Giavazzi, 2002). The BW shock series may therefore fail to capture country-specific phenomena that only became relevant as financial internationalization made it easier for capital to move internationally, and crises triggered large financial flows. ${ }^{9}$

\footnotetext{
${ }^{9}$ The empirical implications of capital flows for labor markets outlined in Section 3 can in fact be traced to early observations by Blanchard (1997, p.130), who noted that the medium run labor demand model's predictions could be biased by the assumption "that each economy was on its steady-state growth path [;] if below, an increase in the ratio of capital to labor allows wages to grow faster than TFP without adverse effects on unemployment," and by Blanchard (2006), who noted that in countries such as Spain unemployment was declining strongly in the absence of noticeable labor market deregulation or favorable productivity developments.
} 
Figure 4 shows that current account / GDP ratios around 1990 began to fluctuate widely and more asymmetrically than the BW shocks. ${ }^{10}$ Across the sample's advanced countries, a common portion of international imbalances may have been driven by capital flows to and from emerging countries, but current account developments were very heterogeneous especially among members of Europe's Economic and Monetary union. To the extent that current account variation is driven by easier international mobility of capital, it is a plausibly exogenous driver of labor market conditions, as domestic investment financed by foreign wealth increases demand for complementary labor (consumption-smoothing borrowing by previously liquidity-constrained countries has a similarly positive labor demand effect in their economies' non-tradable sectors).

If asymmetric current account developments are significantly related to unemployment, then labor market shocks are poorly represented by common period dummies. One way to assess the labor market relevance of financial integration is to control for its empirical manifestation in unemployment regressions. Tables 7 and 8 include a proxy of the size and direction of capital flows to the BW capstone regressions that in Tables 4 and 5 recently cease to estimate sensible coefficients. Current account / GDP ratios are insignificant in column 1's original BW sample, suggesting that their specification was appropriate at the time. However they are positively and strongly associated with unemployment in column 2 (which includes the more recent data) and column 3 (which drops the earliest third of the time periods): a positive partial association between unemployment and current account surpluses captures the recently stronger association of external balances swings with country-specific cyclical dynamics, which as discussed in Section 3.3 may plausibly have been driven by tighter international economic integration.

Of course, including the current account in the linear combination of shocks fails to account fully for unemployment developments in all countries, and Figure 5 suggests that the shocks of Table 8 do not predict overall unemployment changes much better than those of Table 5 do in Figure 3 . And current accounts are also endogenously driven by heterogeneous productivity growth expectations and other factors relevant to labor markets outcomes. To the extent that an interesting component of both labor market and capital flow booms and boosts was jointly driven by international integration, however, it is empirically plausible let it play a role similar to that of the BW "shocks" in driving country-specific unemployment. And when controlling for current accounts, the coefficient of TFP

\footnotetext{
${ }^{10}$ Capital stock estimates are somewhat sparsely available in the AMECO database, but it would be complicated and much beyond the scope of this paper to model domestic savings' contribution to capital accumulation.
} 
growth is insignificant, rather than strongly significant but wrongly signed, and so is the labor share-based demand shock. Tighter financial integration does appear to imply that current accounts capture labor market conditions better than indicators meant to represent closed-economy factors. While arguably most relevant to the euro area experience, also in the broader panel data set analyzed here this approach turns out to have considerable traction in rescuing BW-type specifications.

\subsection{Capital flows and reforms}

In regressions that control for institutions, the international mobility of capital proxied by current account variation should in theory and does empirically associate deficits to lower unemployment, and surpluses to higher unemployment. In Table 8 shocks are interacted with the original BW set of time-invariant institutions. The most robustly relevant among them turns out to be the "Coordination" index, constructed in the 1980s to account for persistently low unemployment in small, homogeneous, Scandinavian countries, and rooted in country-specific industrial relations history and cultural features (Blanchard and Philippon, 2006).

Theory associates economic integration also with institutional reforms that partly offset that effect, and tend to decrease employment in deficit countries (Bertola, 2017): for a capital-importing country, the politico-economic optimal employment is lower (relative to the higher laissez-faire level implied by capital inflows) in more integrated financial market; conversely, exogenously more intense capital flows imply that capital-exporting countries not only experience lower labor demand but also have stronger incentives to deregulate their labor markets. This theoretical result is consistent with the labor reform evidence generated by adoption of a common currency by some European countries, a clearly identified and arguably exogenous financial integration shock (Bertola, 2016), and is arguably relevant to the most recent portion of the broader dataset analyzed here: if reforms increase labor market rigidity and decrease TFP in countries where capital inflows reduce unemployment, the data generating process can yield a negative coefficient for TFP in descriptive BW regressions that, as in Tables 4 and 5 , do not control for capital inflows.

Anticipations and lags make it difficult to disentangle labor demand and reform effects in the data. Seeking suggestive evidence, Table 9 asks the updated BW dataset whether labor market deregulation is associated with current account surpluses. The answer is a qualified "yes". Columns 1 and 2 regress 5-period changes of labor tax wedges and unemployment replacement rates on 5-year average current account/GDP ratios, with country and period fixed effects (the coefficients estimated 
without fixed effects are similar in sign and significance). Significantly negative coefficients indicate that current account surpluses are correlated with labor market deregulation. If variation in the latter respect is treated as exogenous, driven perhaps by randomly different amounts of attention paid to the advice of international organizations by different countries' policy-makers, then the data can be read as saying that labor market deregulation improves countries' competitiveness. The observed pattern, however, is also that implied across differently capital-abundant countries by easier capital mobility when, as in Section 3's model, distributional motives shape labor market institutions.

The estimated relationships could be spuriously driven by unobservable factors, such as political shifts that trigger labor market deregulation and improve competitiveness. The regressions in columns 3 and 4 of Table 9 attempt to isolate the role of financial integration instrumenting the current account with indicators of gross financial integration (Broner and others, 2013) and dummies indicating adoption of the euro by 10 countries, starting in the 2000-04 period (without accounting for the financial integration impact of the subsequent crises). These instruments are meant to amplify the portion of current account variation that reflects easier international investment. They cannot disentangle the effects of positive and negative capital flows, however, and their exclusion from the second stage may be invalid if political factors drive both labor market reforms and international financial deregulation. The estimated slope coefficients are negative, consistently with Section 3's simple model. But the instruments are weak, and the coefficients are statistically significant only when fixed effects are omitted and only for the labor tax wedge (perhaps suggesting that the portion of current account variation due to financial integration is more relevant to government budgets than to labor market deregulation).

\subsection{Unemployment, shocks, and changing institutions}

Table 10 explores the explanatory power of institutions and shocks for unemployment in the extended BW dataset. Many unobservable sources of variation certainly matter for unemployment. Those that are constant over time can be controlled by the country fixed effects included in the regressions along with the four institutions measured on a time-varying basis and shocks (and the Portuguese revolution dummy).

These data and simple theory do not disagree with each other: all slope coefficients have the expected positive sign when they are significant. Insignificance of employment protection is not theoretically surprising because higher turnover costs reduce both unemployment inflows and outflows, 
and have small and ambiguous average effects. Labor taxation should (all else equal) reduce both labor supply and labor demand without increasing unemployment, but its significantly positive coefficient suggests that large tax wedges are positively correlated with institutional constraints on wage flexibility. Time-varying union density might in principle capture some of those factors. In practice, its insignificant coefficient in column 1 suggests that it poorly captures the relevant institutional features, which may be more appropriately (but also more imprecisely and subjectively) measured by "coverage" and "coordination" indices. All three BW shocks are significant and correctly signed in column 1 , but only the real interest rate is robust to controlling for period effects in column 2 : the empirical time variation of TFP growth and labor shares is empirically hard to distinguish from that of other unobservable unemployment determinants, and the same is the case for unemployment insurance generosity. Columns 3 and 4 include the current account to GDP ratio, which is positive but insignificant when period effects are included; controlling for the variation captured by period effects or the current account yields a positive and significant coefficient estimate for union density.

A causal interpretation of these regressions is only warranted if exogenous political and economic factors drive the variation of institutions (and of shocks). In accounting terms, excluding institutions would lower the $R^{2}$ of the regressions in Table 10 by about 0.05 (without period effects) or 0.03 (with period effects); excluding shocks instead, the $R^{2}$ declines by 0.12 or 0.04 , respectively. This and the broadly sensible pattern of coefficients suggest that, over the longer time span of the extended sample, unemployment covaries with institutions directly, and not just with their shocks interaction.

Theoretically plausible interactions may also be empirically relevant, however. A moderate dose of theory-inspired specification searching allows regressions to detect some sensible patterns believably, at least for readers familiar with the once popular and influential (European) unemployment country-panel regressions. As discussed in Section 3.2, for example, the strength of the empirical relationship between unemployment and the labor-share-based indicator of the size and direction of labor demand shocks depends on a variety of technological and institutional factors, of which one is at least imprecisely observable and of policy interest: in countries and periods where employment protection is more stringent, not only wages but also and especially employment react sluggishly to shocks. Hence, the labor share can fluctuate without much employment variation, and unemployment should be less sensitive to variation of the BW labor demand shocks. To detect this in the data the regressions of Table 11 include the real rate and current account/GDP, the more significant and robust shocks in Table 10, along with the first difference rather than the level of the labor demand 
shock, its interaction with time-varying employment protection, other time-varying institutions, and country fixed effects. The interaction term is estimated to be negative, in line with theoretical expectations, and significantly so when the regressions control for lagged unemployment. The large and very significant coefficient of the lagged dependent variable might call for further refinements, which could doubtlessly yield results that adhere more closely to theoretical expectations.

\section{Concluding comments}

Blanchard (2006) recognized that macroeconomists "had entered the 1970s without a model of the natural rate, and had not anticipated stagflation" and that they had later found it fruitful to explain unemployment with "adverse shocks interacting with country-specific collective bargaining structures" That approach captured key features of the data when institutions set up around 1970 were confronted by productivity slowdowns and restrictive monetary policies, and ripe for the flexibility-oriented reforms advocated by OECD (1994) and many others. Its inability to fit more recent data suggests that the world has changed in ways that require revision of empirical models and perhaps also of policy advice.

Because institutional reforms over the past two decades are diverse and poorly captured by country and period fixed effects, regressions should include the main effect of institutions, not only their interaction with shocks. Country-specific reforms may perhaps have been triggered by persuasive research-based policy advice, but the politico-economic mechanisms that jointly shape unemployment and policies are only beginning to be understood. In theory, unemployment can be a natural side effect of institutions meant to redistribute welfare across individuals, and is shaped by international economic integration as well as by other structural and political factors. Empirically, macroeconomic shocks and institutional reforms account for a large portion of unemployment's variation, and capital mobility plays a significant and sensible role both as a shock determining unemployment at given institutions, and as a driver of institutional change.

The BW specification offered remarkably robust and interpretable results on the then-available sample. Current account variation is strongly and robustly associated to unemployment in more recent decades. Its association with institutional reforms, while more elusive, offers intriguing empirical support to a distributional interpretation of labor market institutions and reforms, and can be of interest to those who need to formulate and express policy advice. Institutions and policies 
have pros and cons that differ not only across countries and over time (Blanchard, Jaumotte and Loungani, 2014) but also across individuals. If labor policy has distributional as well as efficiencyoriented objectives, its configuration reflects the decisive political coalition's objectives and on the conditions in which it is implemented. Research economists can plausibly claim to have better information than the public about the varying intensity of institutions' pros and cons, but their advice should not disregard distributional implications. 


\section{References}

Baccaro, Lucio and Diego Rei, 2007. Institutional Determinants of Unemployment in OECD Countries: Does the Deregulatory View Hold Water? International Organization 61, 527-569.

Bagliano, Fabio-Cesare and Giuseppe Bertola, 2007. Models for Dynamic Macroeconomics. Oxford University Press, Oxford and New York.

Bassanini, Andrea, and Romain Duval, 2006. The determinants of unemployment across OECD countries: Reassessing the role of policies and institutions. OECD Economic Studies 42 (1), $7-86$.

Bertola, Giuseppe, 2015. What Is Natural About Unemployment? Policy sources and implications of labor market rigidities. In: Re-evaluating labor market dynamics, Federal Reserve Bank of Kansas City, Kansas City, 421-460.

Bertola, Giuseppe, 2016. Labor policies and capital mobility in theory and in EMU. European Economic Review 87, 62-77.

Bertola, Giuseppe, 2017. Wedges: Distribution, Distortions, and Market Integration. CEPR DP11980.

Bertola, Giuseppe, Francine D. Blau, and Lawrence M. Kahn, 2002. Comparative Analysis of Labor Market Outcomes: Lessons for the US from International Long-Run Evidence. In: The Roaring Nineties: Can Full Employment Be Sustained?, ed. by A. B.Krueger and R.M.Solow, New York: Russell Sage Foundation, 159-218.

Bertola, Giuseppe, Francine D. Blau and Lawrence M. Kahn, 2007. Labor Market Institutions and Demographic Employment Patterns. Journal of Population Economics 20, 833-867.

Blanchard, Olivier J., 1997. The Medium Run. Brookings Papers on Economic Activity 2:1997, $89-158$.

Blanchard, Olivier J., 2006. European unemployment: the evolution of facts and ideas. Economic Policy 45, 5-59.

Blanchard, Olivier J. and Francesco Giavazzi, 2002. Current Account Deficits in the Euro Area: The End of the Feldstein-Horioka Puzzle? Brookings Papers on Economic Activity 2:2002, $147-186$.

Blanchard, Olivier J., Florence Jaumotte and Prakash Loungani, 2014. Labor market policies and IMF advice in advanced economies during the Great Recession. IZA Journal of Labor Policy $3: 2$.

Blanchard, Olivier J. and Thomas Philippon, 2004. The Quality of Labor Relations and Unemployment. unpublished (http://web.mit.edu/blanchar/www/articles.html) 
Blanchard, Olivier J. and Thomas Philippon, 2006. Unemployment and the Quality of Labor Relations II. unpublished (http://web.mit.edu/blanchar/www/articles.html)

Blanchard, Olivier J. and Lawrence H. Summers, 1986. Hysteresis and the European Unemployment Problem. In: S. Fischer (Ed.), NBER Macroeconomics Annual 1987, Cambridge: MIT Press, 15-78.

Blanchard, Olivier J. and Justin Wolfers, 2000. The Role of Shocks and Institutions in the Rise of European Unemployment: The Aggregate Evidence. Economic Journal 110:462, C1-33.

Broner, Fernando, Tatiana Didier, Aitor Erce and Sergio Schmukler, 2013. Gross Capital Flows: Dynamics and Crises. Journal of Monetary Economics 60(1) 113-133.

Hall, Robert E., 2005. Employment Fluctuations with Equilibrium Wage Stickiness. American Economic Review 95, 50-65.

Michaillat, Pascal, 2012. Do Matching Frictions Explain Unemployment? Not in Bad Times. American Economic Review 102, 1721-50.

Mortensen, Dale M. and Christopher Pissarides, 1994. Job Creation and Job Destruction in the Theory of Unemployment. Review of Economic Studies 61, 397-415.

Nickell, Stephen, 1997. Unemployment and Labor Market Rigidities: Europe versus North America. Journal of Economic Perspectives 11(3), 55-74.

Nickell, Stephen, Luca Nunziata and Wolfgang Ochel, 2005. Unemployment in the OECD Since the 1960s. What Do We Know? Economic Journal 115:500, 1-27.

OECD, 1994. The Jobs Study: Facts, Analysis, Strategy. Paris: OECD.

Phelps, Edmund and Gylfi Zoega, 1998. Natural Rate Theory and OECD Unemployment. Economic Journal 108, 782-801. 


\section{Unemployment rate, AMECO}
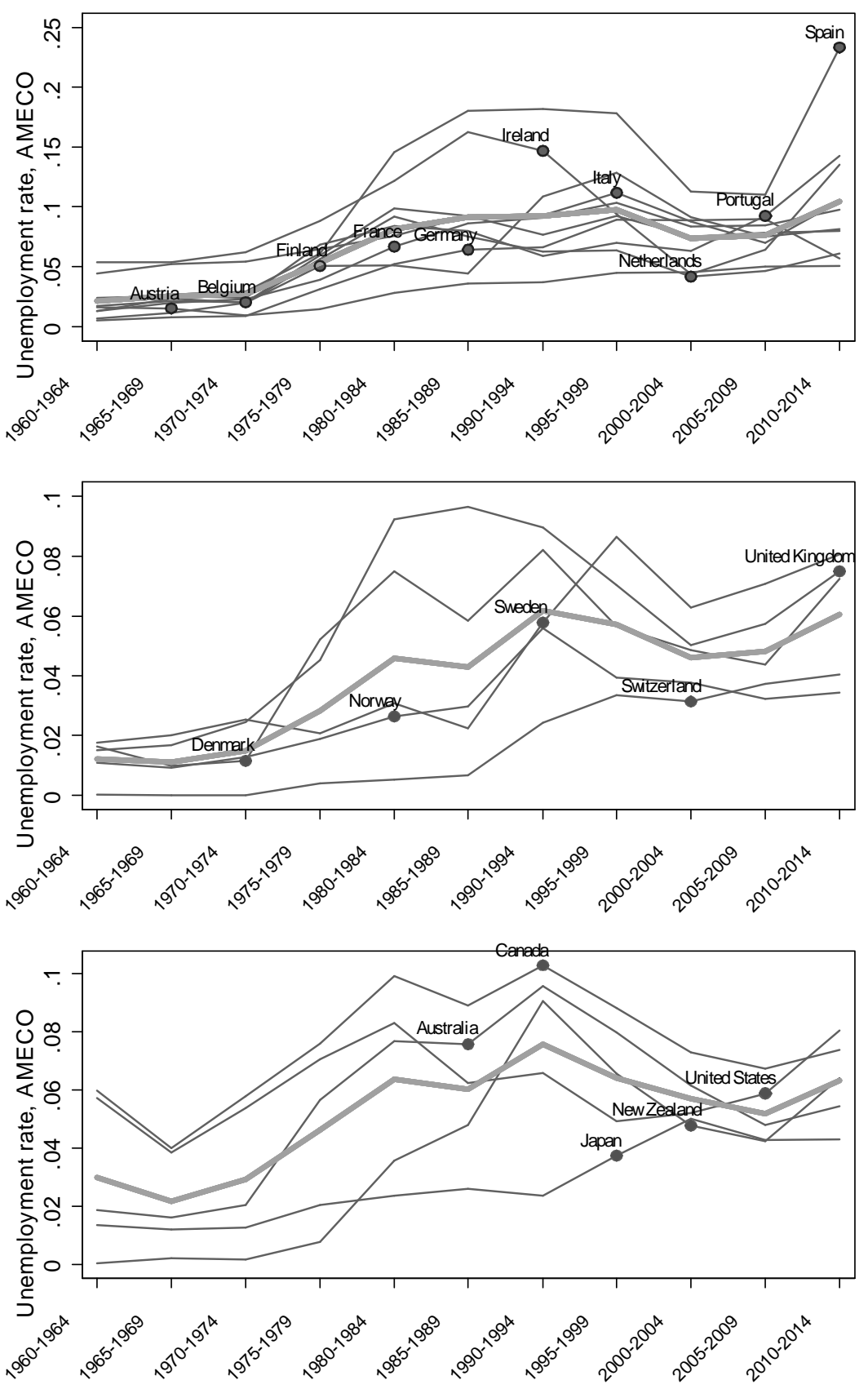

Figure 1: Unemployment rates by 5-year periods (source: AMECO). Thick lines plot unweighted averages. 

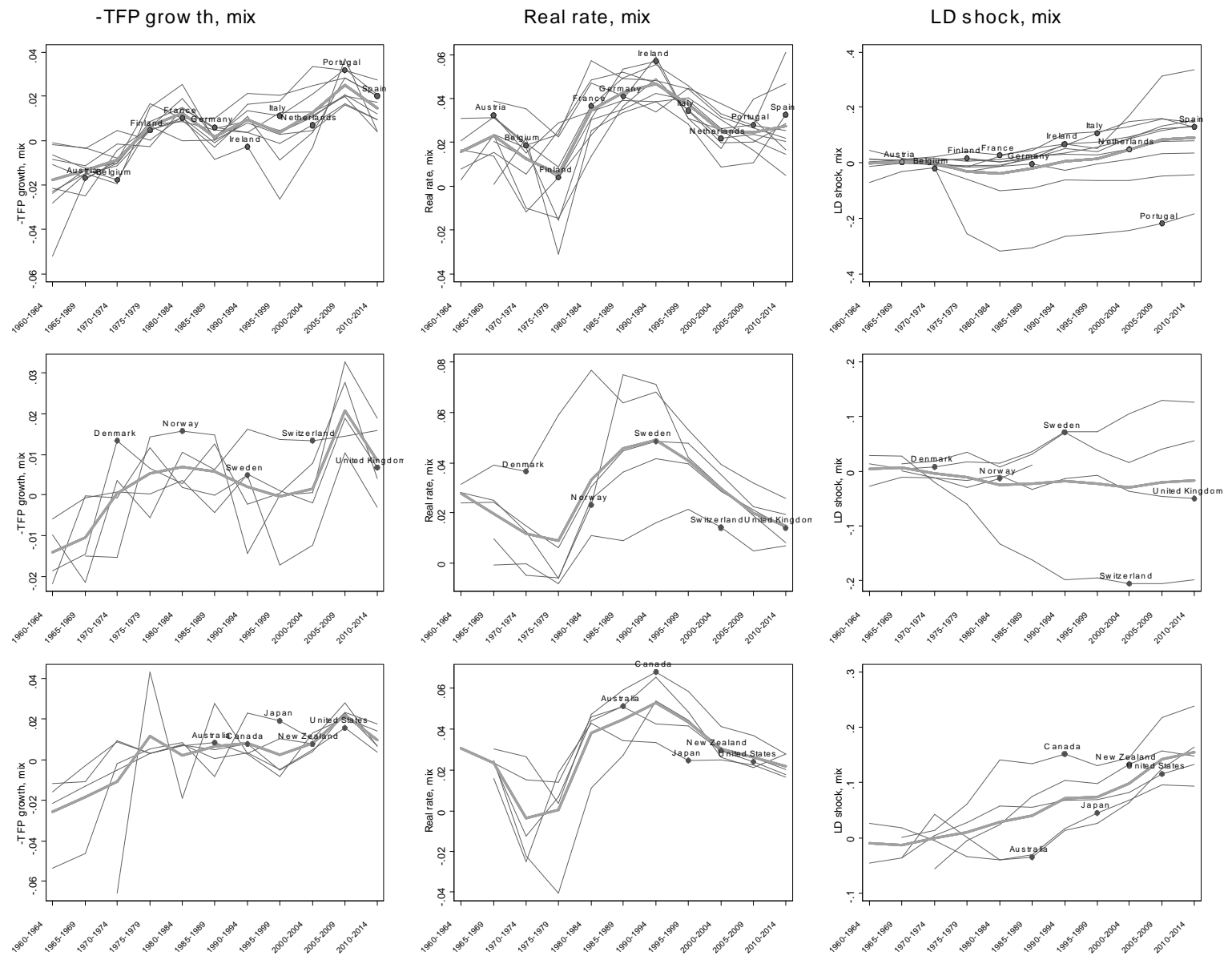

Figure 2: Time paths of 5-period average shocks indicators constructed on the basis of BW definitions using AMECO and OECD annual data (see the Data Appendix for definitions and sources). Thick lines plot unweighted averages. 

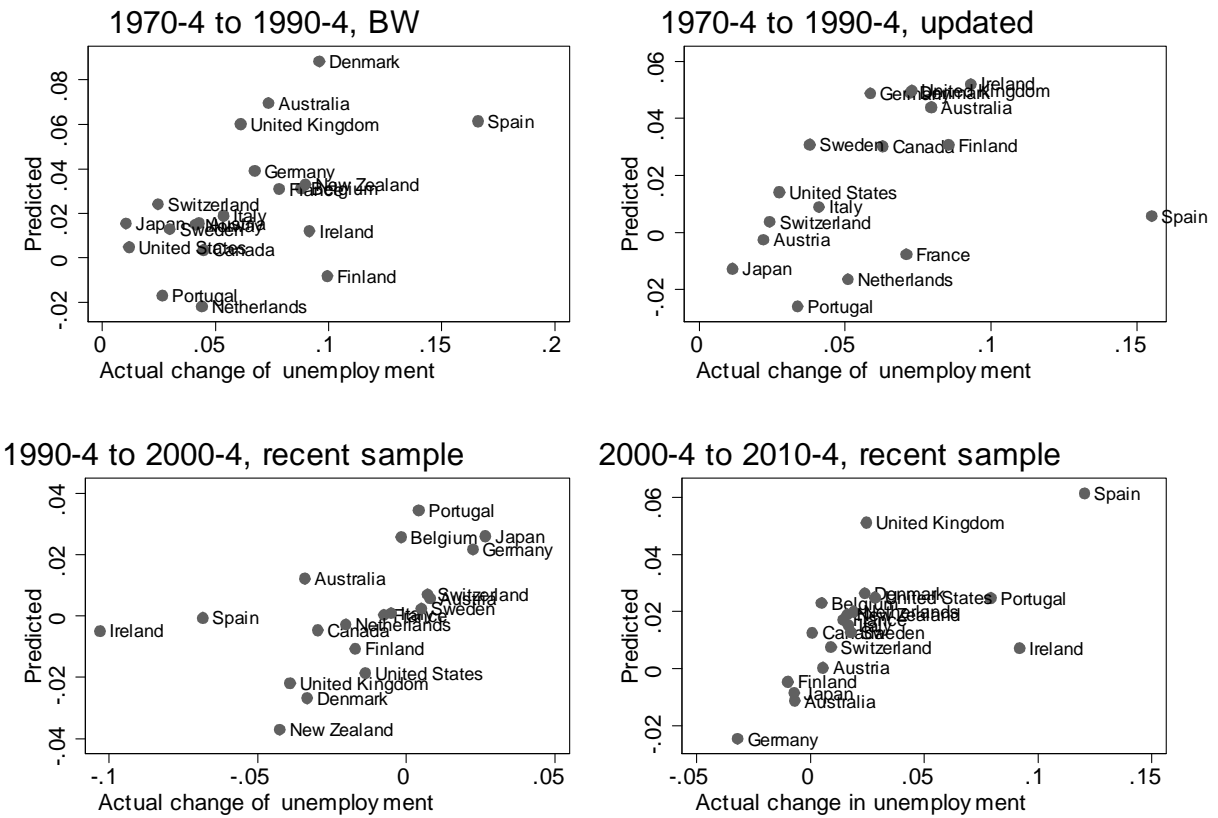

Figure 3: Actual unemployment changes and predictions of the regressions of Table 5 column 1 (top left panel), Table 5 column 2 (top right panel), and Table 5 column 3 (bottom panels). 


\section{Current account / GDP}
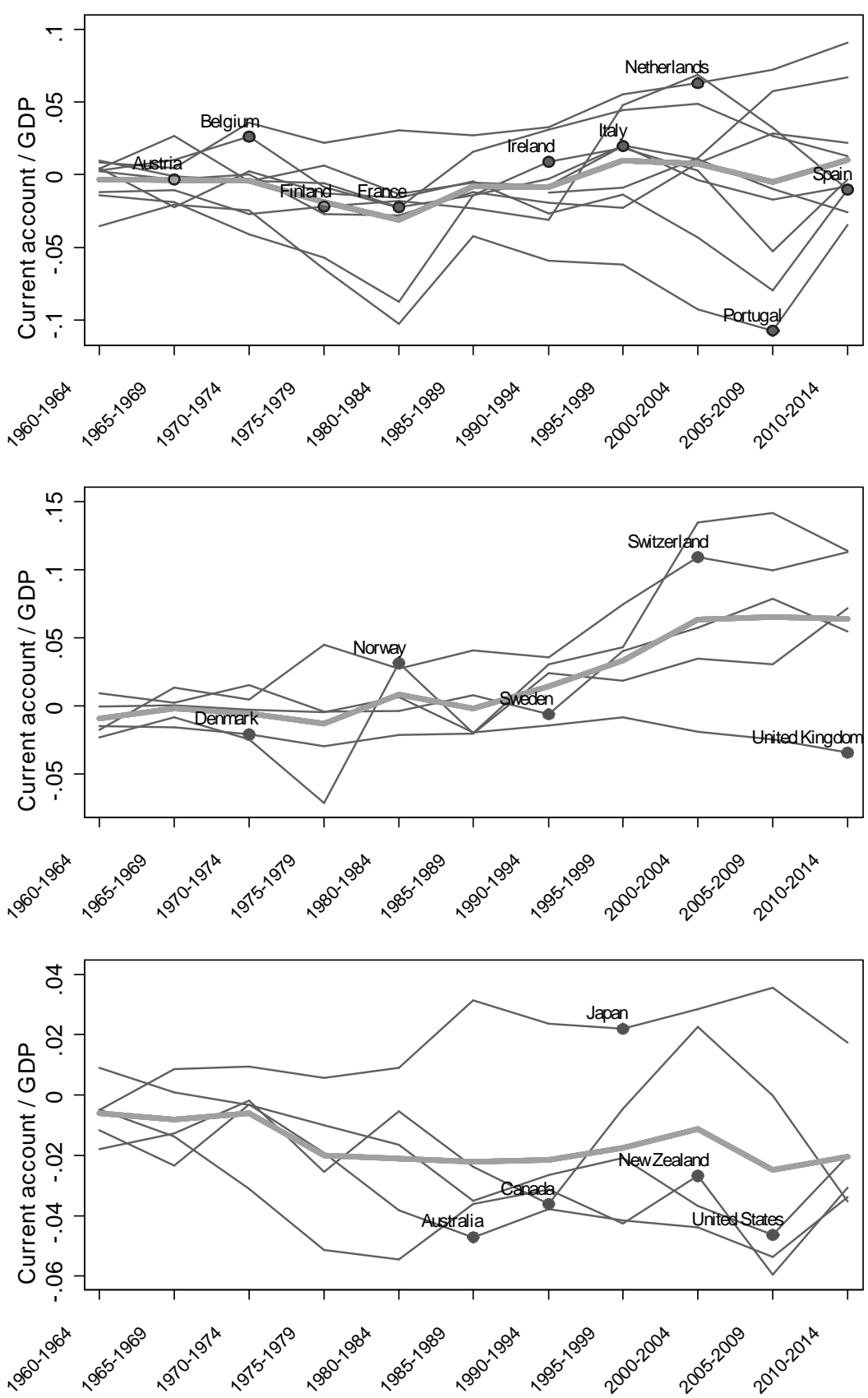

Figure 4: Current account / GDP ratios over 5-year periods (source: AMECO). Thick lines plot unweighted averages. 

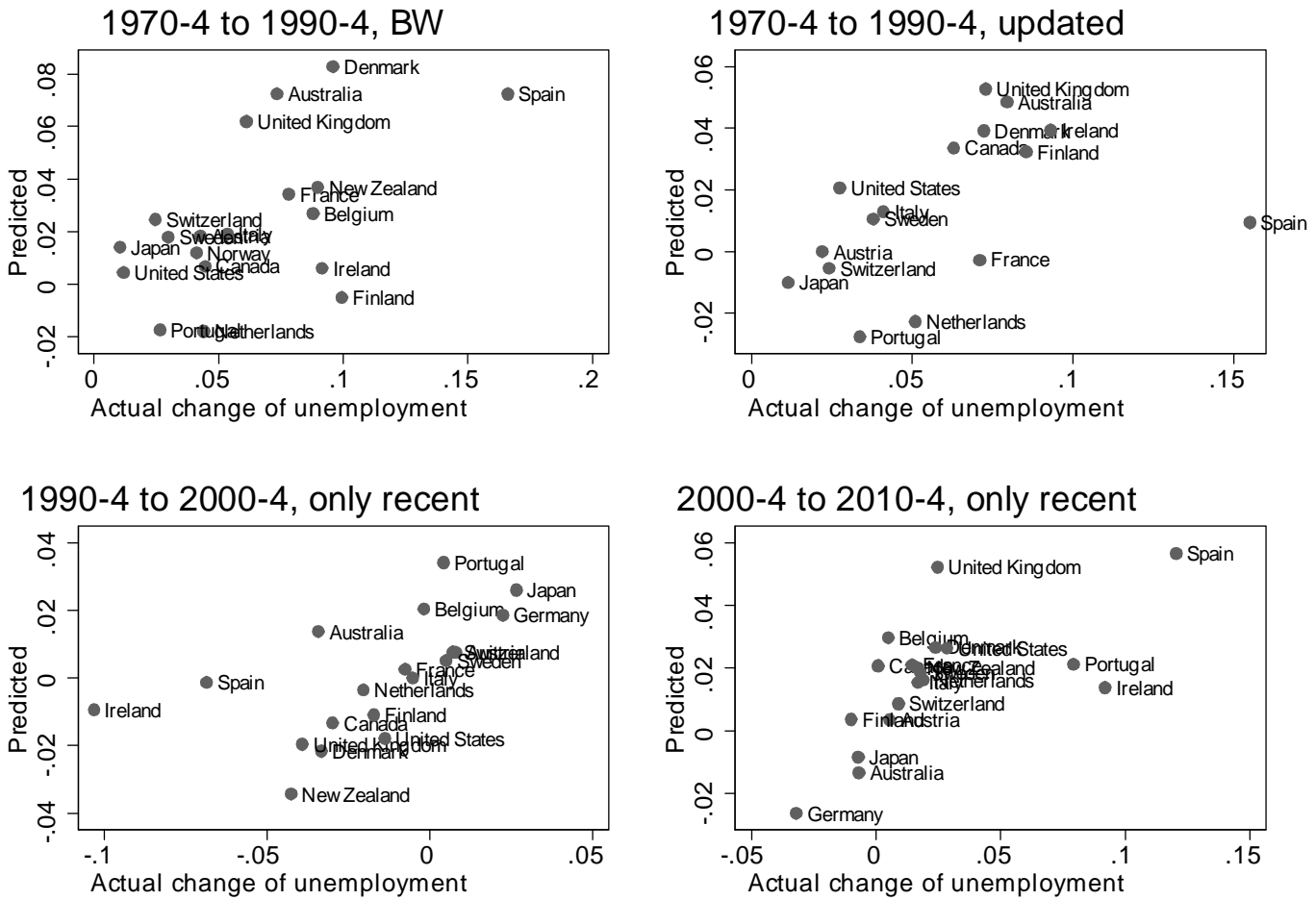

Figure 5: Actual unemployment changes and predictions of the regressions of Table 8 column 1 (top left panel), Table 8 column 2 (top right panel), and Table 8 column 3 (bottom panels). 
Table 1: Replication and update of BW Table 1

\begin{tabular}{llll}
\hline \hline & \multicolumn{1}{c}{$(1)$} & \multicolumn{1}{c}{$(2)$} & \multicolumn{1}{c}{$(3)$} \\
\hline UI repl.rate & $0.0172^{* * *}$ & $0.0158^{* * *}$ & $0.0446^{* * *}$ \\
& $(4.67)$ & $(4.37)$ & $(2.65)$ \\
UI benef.length & $0.207^{* * *}$ & $0.165^{* * *}$ & 0.0694 \\
& $(5.30)$ & $(3.82)$ & $(0.32)$ \\
Active labor policy & $0.0178^{* *}$ & 0.00398 & 0.0329 \\
& $(2.37)$ & $(0.63)$ & $(0.92)$ \\
Empl.protection & $0.0455^{* * *}$ & $0.0466^{* * *}$ & 0.0783 \\
& $(3.42)$ & $(3.06)$ & $(1.11)$ \\
Tax wedge & $0.0181^{* * *}$ & 0.00644 & -0.00244 \\
& $(2.63)$ & $(1.05)$ & $(-0.08)$ \\
Union coverage & 0.0927 & 0.149 & 1.289 \\
& $(0.58)$ & $(0.89)$ & $(1.56)$ \\
Union density & $0.00867^{*}$ & 0.00122 & $0.0351^{*}$ \\
& $(1.87)$ & $(0.30)$ & $(1.78)$ \\
Coordination & $0.304^{* * *}$ & $0.283^{* * *}$ & $1.572^{* * *}$ \\
& $(6.08)$ & $(5.13)$ & $(4.24)$ \\
\hline R-Square & 0.89 & 0.95 & 0.82 \\
Parameters & 33 & 37 & 32 \\
Observations & 159 & 220 & 120 \\
\hline \hline
\end{tabular}

$t$ statistics in parentheses

Dependent variable: Unemployment rate

Column 1: original BW dataset.

Column 2: AMECO unemployment, BW institutions.

Column 3: only recent sample.

${ }^{*} \mathrm{p}<0.1,{ }^{* *} \mathrm{p}<0.05,{ }^{* * *} \mathrm{p}<0.01$ 
Table 2: Replication and update of BW Table 2 col 1

\begin{tabular}{llll}
\hline \hline & \multicolumn{1}{c}{$(1)$} & \multicolumn{1}{c}{$(2)$} & \multicolumn{1}{c}{$(3)$} \\
\hline UI repl.rate & $0.0153^{* * *}$ & $0.0138^{* * *}$ & $0.0446^{* *}$ \\
& $(3.64)$ & $(3.61)$ & $(2.25)$ \\
UI benef.length & $0.223^{* * *}$ & $0.175^{* * *}$ & 0.0694 \\
& $(4.86)$ & $(3.93)$ & $(0.28)$ \\
Active labor policy & $0.0150^{* *}$ & 0.00132 & 0.0329 \\
& $(1.98)$ & $(0.20)$ & $(0.90)$ \\
Empl.protection & $0.0556^{* * *}$ & $0.0529^{* * *}$ & 0.0783 \\
& $(3.02)$ & $(2.87)$ & $(0.75)$ \\
Tax wedge & 0.0126 & 0.00167 & -0.00244 \\
& $(1.64)$ & $(0.25)$ & $(-0.07)$ \\
Union coverage & -0.0696 & 0.0156 & 1.289 \\
& $(-0.36)$ & $(0.08)$ & $(1.15)$ \\
Union density & $0.00874^{*}$ & 0.000394 & 0.0351 \\
& $(1.68)$ & $(0.08)$ & $(1.37)$ \\
Coordination & $0.274^{* * *}$ & $0.252^{* * *}$ & $1.572^{* * *}$ \\
& $(4.89)$ & $(4.25)$ & $(3.60)$ \\
\hline R-Square & 0.82 & 0.93 & 0.66 \\
Parameters & 21 & 25 & 21 \\
Observations & 159 & 220 & 120 \\
\hline \hline
\end{tabular}

$t$ statistics in parentheses

Dependent variable: Unemployment rate

Column 1: original BW dataset.

Column 2: AMECO unemployment, BW institutions.

Column 3: only recent sample.

$* \mathrm{p}<0.1,{ }^{* *} \mathrm{p}<0.05,{ }^{* * *} \mathrm{p}<0.01$ 
Table 3: Replication and update of BW Table 3

\begin{tabular}{lllllc}
\hline \hline & \multicolumn{1}{c}{$(1)$} & \multicolumn{1}{c}{$(2)$} & \multicolumn{1}{c}{$(3)$} & \multicolumn{1}{c}{$(4)$} & $(5)$ \\
\hline UI repl rate, 1st year & $0.00728^{*}$ & & & & \\
& $(1.74)$ & & & & \\
UI repl.rate & $0.0187^{* * *}$ & $0.0159^{* * *}$ & $0.0146^{* * *}$ & $0.0155^{* * *}$ & $0.0146^{* * *}$ \\
& $(3.06)$ & $(4.05)$ & $(3.61)$ & $(3.65)$ & $(3.34)$ \\
Active labor policy & 0.00538 & $0.0185^{* *}$ & -0.00478 & -0.000268 & \\
& $(0.45)$ & $(2.38)$ & $(-0.82)$ & $(-0.05)$ & \\
Empl.protection & $0.0325^{*}$ & 0.0155 & -0.0337 & 0.0115 & -0.000976 \\
& $(1.68)$ & $(0.23)$ & $(-0.46)$ & $(0.14)$ & $(-0.02)$ \\
Tax wedge & 0.0151 & $0.0217^{* * *}$ & $0.0128^{*}$ & $0.0150^{* *}$ & $0.0208^{* * *}$ \\
& $(1.63)$ & $(3.01)$ & $(1.74)$ & $(2.07)$ & $(3.01)$ \\
Union coverage & $0.389^{* *}$ & $0.742^{* * *}$ & $0.611^{* * *}$ & $0.522^{* * *}$ & \\
& $(2.41)$ & $(5.75)$ & $(4.39)$ & $(3.98)$ & \\
Union density & 0.000116 & 0.00483 & -0.00817 & -0.00144 & $-0.00493^{*}$ \\
& $(0.02)$ & $(0.96)$ & $(-1.63)$ & $(-0.38)$ & $(-1.72)$ \\
Coordination & $0.324^{* * *}$ & $0.373^{* * *}$ & $0.236^{* * *}$ & $0.276^{* * *}$ & \\
& $(6.78)$ & $(5.90)$ & $(4.36)$ & $(4.29)$ & \\
\hline R-Square & 0.87 & 0.87 & 0.94 & 0.94 & 0.93 \\
Parameters & 33 & 32 & 36 & 36 & 33 \\
Observations & 159 & 159 & 220 & 220 & 220 \\
\hline \hline
\end{tabular}

$t$ statistics in parentheses

Dependent variable: Unemployment rate

Column 1: original dataset, replicates BW col.2.

Column 2: original dataset, replicates BW col.4.

Column 3: extended data, time-varying UI repl.rate and EPL.

Column 4: time-varying UI repl.rate and EPL, tax, union density.

Column 5: no time-invariant institutions.

$* \mathrm{p}<0.1,{ }^{* *} \mathrm{p}<0.05,{ }^{* * *} \mathrm{p}<0.01$ 
Table 4: Replication and update of BW Table 4, column 1

\begin{tabular}{llll}
\hline \hline & \multicolumn{1}{c}{$(1)$} & \multicolumn{1}{c}{$(2)$} & \multicolumn{1}{c}{$(3)$} \\
\hline -TFP growth & $0.425^{* * *}$ & $0.483^{* * *}$ & $-0.448^{*}$ \\
& $(2.79)$ & $(3.40)$ & $(-1.73)$ \\
& & & \\
Real rate & $0.618^{* * *}$ & $0.840^{* * *}$ & $0.803^{* * *}$ \\
& $(5.15)$ & $(8.32)$ & $(4.58)$ \\
& & & \\
LD shock & $0.177^{* *}$ & 0.0512 & $0.102^{*}$ \\
& $(2.40)$ & $(1.54)$ & $(1.82)$ \\
\hline R-Square & 0.66 & 0.65 & 0.75 \\
Parameters & 23 & 23 & 22 \\
Observations & 131 & 198 & 115 \\
\hline \hline
\end{tabular}

$t$ statistics in parentheses

Dependent variable: Unemployment rate

Column 1: BW dataset (with Port.rev.dummy).

Column 2: AMECO unemployment, spliced shocks.

Column 3: only recent sample.

* $\mathrm{p}<0.1, * * \mathrm{p}<0.05, * * * \mathrm{p}<0.01$ 
Table 5: Replication and update of BW Table 5, column 1

\begin{tabular}{|c|c|c|c|}
\hline & $(1)$ & $\overline{(2)}$ & $(3)$ \\
\hline -TFP growth & $\begin{array}{l}0.715^{* * *} \\
(5.00)\end{array}$ & $\begin{array}{l}0.755^{* * *} \\
(4.18)\end{array}$ & $\begin{array}{l}-0.219^{* *} \\
(-2.00)\end{array}$ \\
\hline Real rate & $\begin{array}{l}0.471^{* * *} \\
(5.20)\end{array}$ & $\begin{array}{l}0.859^{* * *} \\
(8.61)\end{array}$ & $\begin{array}{l}0.651^{* * *} \\
(4.82)\end{array}$ \\
\hline LD shock & $\begin{array}{l}0.190^{* *} \\
(2.10)\end{array}$ & $\begin{array}{l}0.0177 \\
(0.47)\end{array}$ & $\begin{array}{l}0.0176 \\
(1.00)\end{array}$ \\
\hline UI repl.rate & $\begin{array}{l}0.0253^{* * *} \\
(5.04)\end{array}$ & $\begin{array}{l}0.0147^{* * *} \\
(3.24)\end{array}$ & $\begin{array}{l}0.0391^{* * *} \\
(2.79)\end{array}$ \\
\hline UI benef.length & $\begin{array}{l}0.267^{* * *} \\
(4.37)\end{array}$ & $\begin{array}{l}0.229 * * * \\
(3.80)\end{array}$ & $\begin{array}{l}0.209 \\
(1.03)\end{array}$ \\
\hline Active labor policy & $\begin{array}{l}0.0287 \\
(1.66)\end{array}$ & $\begin{array}{l}0.0136 \\
(0.88)\end{array}$ & $\begin{array}{l}0.0150 \\
(0.55)\end{array}$ \\
\hline Empl.protection & $\begin{array}{l}0.0949^{* * *} \\
(3.35)\end{array}$ & $\begin{array}{l}0.0361 \\
(1.38)\end{array}$ & $\begin{array}{l}0.119^{* *} \\
(2.57)\end{array}$ \\
\hline Tax wedge & $\begin{array}{l}0.0334^{* * *} \\
(2.86)\end{array}$ & $\begin{array}{l}0.0210^{*} \\
(1.91)\end{array}$ & $\begin{array}{c}-0.0274 \\
(-1.13)\end{array}$ \\
\hline Union coverage & $\begin{array}{c}-0.502 \\
(-1.56)\end{array}$ & $\begin{array}{l}0.0683 \\
(0.24)\end{array}$ & $\begin{array}{l}0.888 \\
(1.31)\end{array}$ \\
\hline Union density & $\begin{array}{l}0.0342^{* * *} \\
(3.65)\end{array}$ & $\begin{array}{l}-0.00773 \\
(-0.94)\end{array}$ & $\begin{array}{l}0.0272^{*} \\
(1.78)\end{array}$ \\
\hline Coordination & $\begin{array}{l}0.415^{* * *} \\
(4.32)\end{array}$ & $\begin{array}{l}0.192 \\
(1.47)\end{array}$ & $\begin{array}{l}1.144^{* * *} \\
(3.46)\end{array}$ \\
\hline R-Square & 0.91 & 0.92 & 0.84 \\
\hline Parameters & 32 & 32 & 29 \\
\hline Observations & 131 & 198 & 115 \\
\hline
\end{tabular}

$t$ statistics in parentheses

Dependent variable: Unemployment rate

Column 1: BW dataset (with Port.rev.dummy).

Column 2: AMECO unemployment, spliced shocks.

Column 3: only recent sample.

* $\mathrm{p}<0.1, * * \mathrm{p}<0.05, * * * \mathrm{p}<0.01$ 
Table 6: Replication and update of BW Table 6

\begin{tabular}{|c|c|c|c|c|c|}
\hline & $(1)$ & (2) & $(3)$ & $(4)$ & $(5)$ \\
\hline - TFP growth & $\begin{array}{l}0.541^{* * *} \\
(3.57)\end{array}$ & $\begin{array}{l}0.658^{* * *} \\
(3.98)\end{array}$ & $\begin{array}{l}0.748^{* * *} \\
(3.96)\end{array}$ & $\begin{array}{l}0.741^{* * *} \\
(3.89)\end{array}$ & $\begin{array}{l}0.733^{* * *} \\
(4.28)\end{array}$ \\
\hline Real rate & $\begin{array}{l}0.509^{* * *} \\
(5.49)\end{array}$ & $\begin{array}{l}0.505^{* * *} \\
(5.31)\end{array}$ & $\begin{array}{l}0.896^{* * *} \\
(8.77)\end{array}$ & $\begin{array}{l}0.943^{* * *} \\
(8.82)\end{array}$ & $\begin{array}{l}0.937^{* * *} \\
(9.05)\end{array}$ \\
\hline LD shock & $\begin{array}{l}0.172^{*} \\
(1.93)\end{array}$ & $\begin{array}{l}0.177^{*} \\
(1.86)\end{array}$ & $\begin{array}{l}0.0276 \\
(0.83)\end{array}$ & $\begin{array}{l}0.0174 \\
(0.64)\end{array}$ & $\begin{array}{l}0.0465^{*} \\
(1.82)\end{array}$ \\
\hline UI repl rate, 1st year & $\begin{array}{l}0.00813 \\
(1.12)\end{array}$ & & & & \\
\hline UI repl.rate & $\begin{array}{l}0.0133 \\
(1.16)\end{array}$ & $\begin{array}{l}0.0216^{\text {*** }} \\
(3.98)\end{array}$ & $\begin{array}{l}0.00333 \\
(0.49)\end{array}$ & $\begin{array}{l}0.00409 \\
(0.63)\end{array}$ & $\begin{array}{l}0.00473 \\
(0.69)\end{array}$ \\
\hline Active labor policy & $\begin{array}{l}0.00109 \\
(0.06)\end{array}$ & $\begin{array}{l}0.0100 \\
(0.58)\end{array}$ & $\begin{array}{l}-0.00223 \\
(-0.15)\end{array}$ & $\begin{array}{l}0.00193 \\
(0.13)\end{array}$ & \\
\hline Empl.protection & $\begin{array}{l}0.0492 \\
(1.24)\end{array}$ & $\begin{array}{l}0.0940^{*} \\
(1.68)\end{array}$ & $\begin{array}{l}-0.121 \\
(-1.44)\end{array}$ & $\begin{array}{l}-0.0690 \\
(-0.80)\end{array}$ & $\begin{array}{l}-0.0247 \\
(-0.55)\end{array}$ \\
\hline Tax wedge & $\begin{array}{l}0.0181 \\
(1.12)\end{array}$ & $\begin{array}{l}0.0296^{* *} \\
(2.32)\end{array}$ & $\begin{array}{l}0.0285^{*} \\
(1.72)\end{array}$ & $\begin{array}{l}0.0257 \\
(1.43)\end{array}$ & $\begin{array}{l}0.0322^{\text {*** }} \\
(3.44)\end{array}$ \\
\hline Union coverage & $\begin{array}{l}0.214 \\
(0.58)\end{array}$ & $\begin{array}{l}0.526^{* * *} \\
(2.68)\end{array}$ & $\begin{array}{l}0.477 \\
(1.56)\end{array}$ & $\begin{array}{l}0.359 \\
(1.13)\end{array}$ & \\
\hline Union density & $\begin{array}{l}0.0132 \\
(1.19)\end{array}$ & $\begin{array}{l}0.0223^{* * *} \\
(2.88)\end{array}$ & $\begin{array}{l}-0.0198^{* * *} \\
(-3.02)\end{array}$ & $\begin{array}{l}-0.0156^{* * *} \\
(-3.10)\end{array}$ & $\begin{array}{l}-0.0172^{\text {*** }} \\
(-3.67)\end{array}$ \\
\hline Coordination & $\begin{array}{l}0.285^{* *} \\
(2.57) \\
\end{array}$ & $\begin{array}{l}0.518^{* * *} \\
(4.12)\end{array}$ & $\begin{array}{l}0.0853 \\
(0.82)\end{array}$ & $\begin{array}{l}0.104 \\
(1.07)\end{array}$ & \\
\hline R-Square & 0.90 & 0.90 & 0.92 & 0.92 & 0.91 \\
\hline Parameters & 32 & 31 & 31 & 31 & 28 \\
\hline Observations & 131 & 131 & 198 & 198 & 198 \\
\hline
\end{tabular}

$t$ statistics in parentheses

Dependent variable: Unemployment rate

Column 1: original dataset, replicates BW col.2.

Column 2: original dataset, replicates BW col.4.

Column 3: extended data, time-varying UI repl.rate and EPL.

Column 4: time-varying UI repl.rate and EPL, tax, union density.

Column 5: no time-invariant institutions.

${ }^{*} \mathrm{p}<0.1,{ }^{* *} \mathrm{p}<0.05,{ }^{* * *} \mathrm{p}<0.01$ 
Table 7: Controlling for current account in BW Table 4, column 1

\begin{tabular}{llll}
\hline \hline & \multicolumn{1}{c}{$(1)$} & \multicolumn{1}{c}{$(2)$} & \multicolumn{1}{c}{$(3)$} \\
\hline -TFP growth & $0.440^{* * *}$ & $0.482^{* * *}$ & -0.120 \\
& $(2.76)$ & $(3.51)$ & $(-0.49)$ \\
& & & \\
Real rate & $0.593^{* * *}$ & $0.854^{* * *}$ & $1.012^{* * *}$ \\
& $(4.85)$ & $(8.87)$ & $(6.12)$ \\
& & \\
LD shock & $0.171^{* *}$ & 0.0444 & $0.0867^{*}$ \\
& $(2.29)$ & $(1.40)$ & $(1.70)$ \\
Current account / GDP & 0.190 & $0.242^{* * *}$ & $0.375^{* * *}$ \\
& $(1.25)$ & $(3.46)$ & $(4.54)$ \\
\hline R-Square & 0.67 & 0.68 & 0.80 \\
Parameters & 24 & 24 & 23 \\
Observations & 126 & 193 & 114 \\
\hline \hline
\end{tabular}

$t$ statistics in parentheses

Dependent variable: Unemployment rate

Column 1: BW dataset (with Port.rev.dummy).

Column 2: AMECO unemployment, spliced shocks.

Column 3: only recent sample.

${ }^{*} \mathrm{p}<0.1,{ }^{* *} \mathrm{p}<0.05,{ }^{* * *} \mathrm{p}<0.01$ 
Table 8: Controlling for current account in BW Table 5, column 1

\begin{tabular}{|c|c|c|c|}
\hline & (1) & $(2)$ & $(3)$ \\
\hline -TFP growth & $\begin{array}{l}0.742^{\text {*** }} \\
(4.85)\end{array}$ & $\begin{array}{l}0.815^{* * *} \\
(4.58)\end{array}$ & $\begin{array}{l}-0.132 \\
(-1.21)\end{array}$ \\
\hline Real rate & $\begin{array}{l}0.447^{* * *} \\
(4.98)\end{array}$ & $\begin{array}{l}0.910^{* * *} \\
(10.40)\end{array}$ & $\begin{array}{l}0.711^{* * *} \\
(4.77)\end{array}$ \\
\hline LD shock & $\begin{array}{l}0.173^{*} \\
(1.73)\end{array}$ & $\begin{array}{l}-0.000282 \\
(-0.01)\end{array}$ & $\begin{array}{l}0.0181 \\
(0.92)\end{array}$ \\
\hline Current account / GDP & $\begin{array}{l}0.142 \\
(1.26)\end{array}$ & $\begin{array}{l}0.233^{* * *} \\
(3.80)\end{array}$ & $\begin{array}{l}0.110 \\
(1.32)\end{array}$ \\
\hline UI repl.rate & $\begin{array}{l}0.0266^{\text {*** }} \\
(5.32)\end{array}$ & $\begin{array}{l}0.0147^{* * *} \\
(3.46)\end{array}$ & $\begin{array}{l}0.0323^{* *} \\
(2.30)\end{array}$ \\
\hline UI benef.length & $\begin{array}{l}0.261^{* * *} \\
(4.08)\end{array}$ & $\begin{array}{l}0.215^{* * *} \\
(3.67)\end{array}$ & $\begin{array}{l}0.198 \\
(1.00)\end{array}$ \\
\hline Active labor policy & $\begin{array}{l}0.0310^{* *} \\
(1.99)\end{array}$ & $\begin{array}{l}-0.00333 \\
(-0.30)\end{array}$ & $\begin{array}{l}0.00739 \\
(0.23)\end{array}$ \\
\hline Empl.protection & $\begin{array}{l}0.104^{* * *} \\
(3.48)\end{array}$ & $\begin{array}{l}0.0361 \\
(1.45)\end{array}$ & $\begin{array}{l}0.0787 \\
(1.40)\end{array}$ \\
\hline Tax wedge & $\begin{array}{l}0.0341^{* * *} \\
(3.01)\end{array}$ & $\begin{array}{l}0.0189^{*} \\
(1.87)\end{array}$ & $\begin{array}{l}-0.0188 \\
(-0.78)\end{array}$ \\
\hline Union coverage & $\begin{array}{l}-0.624^{*} \\
(-1.81)\end{array}$ & $\begin{array}{l}0.0846 \\
(0.28)\end{array}$ & $\begin{array}{l}0.832 \\
(1.16)\end{array}$ \\
\hline Union density & $\begin{array}{l}0.0358^{\text {*** }} \\
(4.09)\end{array}$ & $\begin{array}{l}-0.00533 \\
(-0.78)\end{array}$ & $\begin{array}{l}0.0208 \\
(1.37)\end{array}$ \\
\hline Coordination & $\begin{array}{l}0.418^{* * *} \\
(4.61)\end{array}$ & $\begin{array}{l}0.213^{*} \\
(1.97)\end{array}$ & $\begin{array}{l}0.918^{* *} \\
(2.59)\end{array}$ \\
\hline R-Square & 0.92 & 0.93 & 0.84 \\
\hline Parameters & 32 & 33 & 30 \\
\hline Observations & 126 & 193 & 114 \\
\hline
\end{tabular}

$t$ statistics in parentheses

Dependent variable: Unemployment rate

Column 1: BW dataset (with Port.rev.dummy).

Column 2: AMECO unemployment, spliced shocks.

Column 3: only recent sample.

${ }^{*} \mathrm{p}<0.1,{ }^{* *} \mathrm{p}<0.05,{ }^{* * *} \mathrm{p}<0.01$ 
Table 9: Capital flows and labor policy reforms

\begin{tabular}{lcccc}
\hline \hline & $(1)$ & $(2)$ & $(3)$ & $(4)$ \\
& Tax wedge & UI replacemente rate & Tax wedge & UI replacemente rate \\
\hline Current account / GDP & $-0.101^{* *}$ & $-0.612^{* * *}$ & $-0.997^{* *}$ & -0.520 \\
& $(-2.25)$ & $(-3.92)$ & $(-2.04)$ & $(-0.83)$ \\
Country fe & Yes & Yes & No & No \\
Period fe & & & & No \\
\hline Parameters & Yes & Yes & 1 & 1 \\
Observations & 29 & 29 & 140 & 140 \\
\hline \hline
\end{tabular}

$t$ statistics in parentheses

Dependent variable: first difference of institutions, as noted.

Columns 3, 4: current account instrumented with gross capital flows and EMU dummy.

${ }^{*} \mathrm{p}<0.1,{ }^{* *} \mathrm{p}<0.05,{ }^{* * *} \mathrm{p}<0.01$ 
Table 10: Linear regressions on the extended and updated BW sample

\begin{tabular}{|c|c|c|c|c|}
\hline & (1) & $(2)$ & $(3)$ & (4) \\
\hline UI repl.rate & $\begin{array}{c}0.000559^{* *} \\
(2.60)\end{array}$ & $\begin{array}{c}-0.0000388 \\
(-0.18)\end{array}$ & $\begin{array}{c}0.000452^{* *} \\
(2.06)\end{array}$ & $\begin{array}{c}0.0000127 \\
(0.06)\end{array}$ \\
\hline Empl.protection & $\begin{array}{c}-0.00239 \\
(-0.55)\end{array}$ & $\begin{array}{c}-0.00474 \\
(-1.33)\end{array}$ & $\begin{array}{c}-0.000223 \\
(-0.06)\end{array}$ & $\begin{array}{c}-0.00408 \\
(-1.08)\end{array}$ \\
\hline Tax wedge & $\begin{array}{c}0.00168^{* *} \\
(2.58)\end{array}$ & $\begin{array}{c}0.00131^{* *} \\
(2.59)\end{array}$ & $\begin{array}{c}0.00125^{* *} \\
(2.05)\end{array}$ & $\begin{array}{c}0.00116^{* *} \\
(2.25)\end{array}$ \\
\hline Union density & $\begin{array}{c}0.000317 \\
(1.61)\end{array}$ & $\begin{array}{c}0.000583^{* * *} \\
(2.89)\end{array}$ & $\begin{array}{c}0.000495^{* * *} \\
(2.78)\end{array}$ & $\begin{array}{c}0.000562^{* * *} \\
(2.79)\end{array}$ \\
\hline - TFP growth & $\begin{array}{c}0.359^{* * *} \\
(2.62)\end{array}$ & $\begin{array}{c}-0.0904 \\
(-0.71)\end{array}$ & $\begin{array}{c}0.390^{* * *} \\
(3.01)\end{array}$ & $\begin{array}{c}-0.0453 \\
(-0.37)\end{array}$ \\
\hline Real rate & $\begin{array}{c}0.690^{* * *} \\
(6.53)\end{array}$ & $\begin{array}{c}0.651^{* * *} \\
(3.13)\end{array}$ & $\begin{array}{c}0.742^{* * *} \\
(6.78)\end{array}$ & $\begin{array}{c}0.700^{* * *} \\
(3.16)\end{array}$ \\
\hline LD shock & $\begin{array}{c}0.0718^{* *} \\
(2.05)\end{array}$ & $\begin{array}{c}-0.0147 \\
(-0.47)\end{array}$ & $\begin{array}{c}0.0769^{* *} \\
(2.41)\end{array}$ & $\begin{array}{c}0.00303 \\
(0.10)\end{array}$ \\
\hline Current account / GDP & & & $\begin{array}{c}0.238^{* * *} \\
(3.39)\end{array}$ & $\begin{array}{c}0.124^{*} \\
(1.95)\end{array}$ \\
\hline Country fe & Yes & Yes & Yes & Yes \\
\hline Period fe & No & Yes & No & Yes \\
\hline R-Square & 0.69 & 0.80 & 0.72 & 0.81 \\
\hline Parameters & 27 & 37 & 28 & 38 \\
\hline Observations & 198 & 198 & 193 & 193 \\
\hline
\end{tabular}

$t$ statistics in parentheses

Dependent variable: Unemployment rate.

Portugal revolution dummy included in all columns.

${ }^{*} \mathrm{p}<0.1,{ }^{* *} \mathrm{p}<0.05,{ }^{* * *} \mathrm{p}<0.01$ 
Table 11: Linear regressions with EPL interaction on the updated BW sample

\begin{tabular}{|c|c|c|c|c|}
\hline & (1) & (2) & (3) & $(4)$ \\
\hline Real rate & $\begin{array}{c}0.691^{* * *} \\
(6.08)\end{array}$ & $\begin{array}{c}0.714^{* * *} \\
(3.16)\end{array}$ & $\begin{array}{c}0.432^{* * *} \\
(3.44)\end{array}$ & $\begin{array}{c}0.643^{* * *} \\
(3.34)\end{array}$ \\
\hline Current account / GDP & $\begin{array}{c}0.184^{* *} \\
(2.53)\end{array}$ & $\begin{array}{c}0.139^{*} \\
(1.96)\end{array}$ & $\begin{array}{c}0.0587 \\
(0.75)\end{array}$ & $\begin{array}{c}0.0732 \\
(1.08)\end{array}$ \\
\hline D Lab.dem. shock & $\begin{array}{c}0.0523 \\
(0.40)\end{array}$ & $\begin{array}{c}0.0169 \\
(0.14)\end{array}$ & $\begin{array}{c}0.0965 \\
(0.82)\end{array}$ & $\begin{array}{c}0.0952 \\
(0.98)\end{array}$ \\
\hline D Lab.dem. shock X Empl.protection & $\begin{array}{c}-0.0691 \\
(-1.43)\end{array}$ & $\begin{array}{c}-0.0190 \\
(-0.43)\end{array}$ & $\begin{array}{c}-0.0836^{* *} \\
(-2.14)\end{array}$ & $\begin{array}{c}-0.0495 \\
(-1.42)\end{array}$ \\
\hline Empl.protection & $\begin{array}{c}-0.00583 \\
(-1.18)\end{array}$ & $\begin{array}{c}-0.00613 \\
(-1.34)\end{array}$ & $\begin{array}{c}-0.00190 \\
(-0.44)\end{array}$ & $\begin{array}{c}-0.00209 \\
(-0.62)\end{array}$ \\
\hline UI repl.rate & $\begin{array}{c}0.000919^{* * *} \\
(3.40)\end{array}$ & $\begin{array}{c}0.000114 \\
(0.46)\end{array}$ & $\begin{array}{c}0.000534^{* * *} \\
(2.84)\end{array}$ & $\begin{array}{c}0.000122 \\
(0.62)\end{array}$ \\
\hline Tax wedge & $\begin{array}{c}0.00156^{* * *} \\
\quad(2.67)\end{array}$ & $\begin{array}{c}0.00138^{* *} \\
(2.46)\end{array}$ & $\begin{array}{c}0.000970^{*} \\
(1.77)\end{array}$ & $\begin{array}{c}0.00101 * \\
(1.96)\end{array}$ \\
\hline Union density & $\begin{array}{c}-0.0000237 \\
(-0.15)\end{array}$ & $\begin{array}{c}0.000470^{*} \\
(1.94)\end{array}$ & $\begin{array}{c}0.000160 \\
(1.09)\end{array}$ & $\begin{array}{c}0.000367 \\
(1.62)\end{array}$ \\
\hline L.u & & & $\begin{array}{c}0.471^{* * *} \\
(4.43)\end{array}$ & $\begin{array}{c}0.492^{* * *} \\
(5.07)\end{array}$ \\
\hline Country fe & Yes & Yes & Yes & Yes \\
\hline Period fe & No & Yes & No & Yes \\
\hline R-Square & 0.71 & 0.80 & 0.78 & 0.85 \\
\hline Parameters & 28 & 37 & 29 & 38 \\
\hline Observations & 180 & 180 & 180 & 180 \\
\hline
\end{tabular}

$t$ statistics in parentheses

Dependent variable: Unemployment rate.

Portugal revolution dummy included in all columns.

${ }^{*} \mathrm{p}<0.1,{ }^{* *} \mathrm{p}<0.05,{ }^{* * *} \mathrm{p}<0.01$ 


\section{Data appendix}

The BW dataset covered 8 time periods, 1960-4 to 1990-4, and 1995+ (typically 1995-6), for 20 OECD countries. The BW data, a sample program, and an appendix outlining data definitions are available at

http://users.nber.org/ jwolfers/data.php .

The BW macroeconomic data were drawn from the OECD Quarterly Business Sector Database (BSDB) diskette, which was discontinued soon afterwards. A file found at http://fmwww.bc.edu/ec-p/data/oecd/bsdb.dta makes it possible to check whether the BW indicator construction and time aggregation was performed correctly (it was, on a somewhat different release of the data).

The Annual Macroeconomic (AMECO) database maintained by the European Commission's Economics and Finance Directorate General,

http://ec.europa.eu/economy_finance/db_indicators/ameco/index_en.htm, includes on a consistently defined basis and since the early 1960s the variables needed to update the BW shock indicators (this article uses the May 2017 AMECO update). For the pre-unification period a "linked Germany" observation is often available, otherwise data for West Germany are used here. Some data are missing in AMECO for a few non-EU countries. As noted below, they are replaced by the BW observation or reconstructed from OECD data.

The Stata dataset documented here and a program can be downloaded at https://sites.google.com/site/gipbert/data

\section{Dependent variable}

The updated sample simply includes the AMECO unemployment rate series, available since the very early 1960s. As shown in the figure it is very similar to that used by BW, but subsequent data revisions do make a substantial difference for some countries in the 5-year periods that were the most recent at the time BW was drafted.
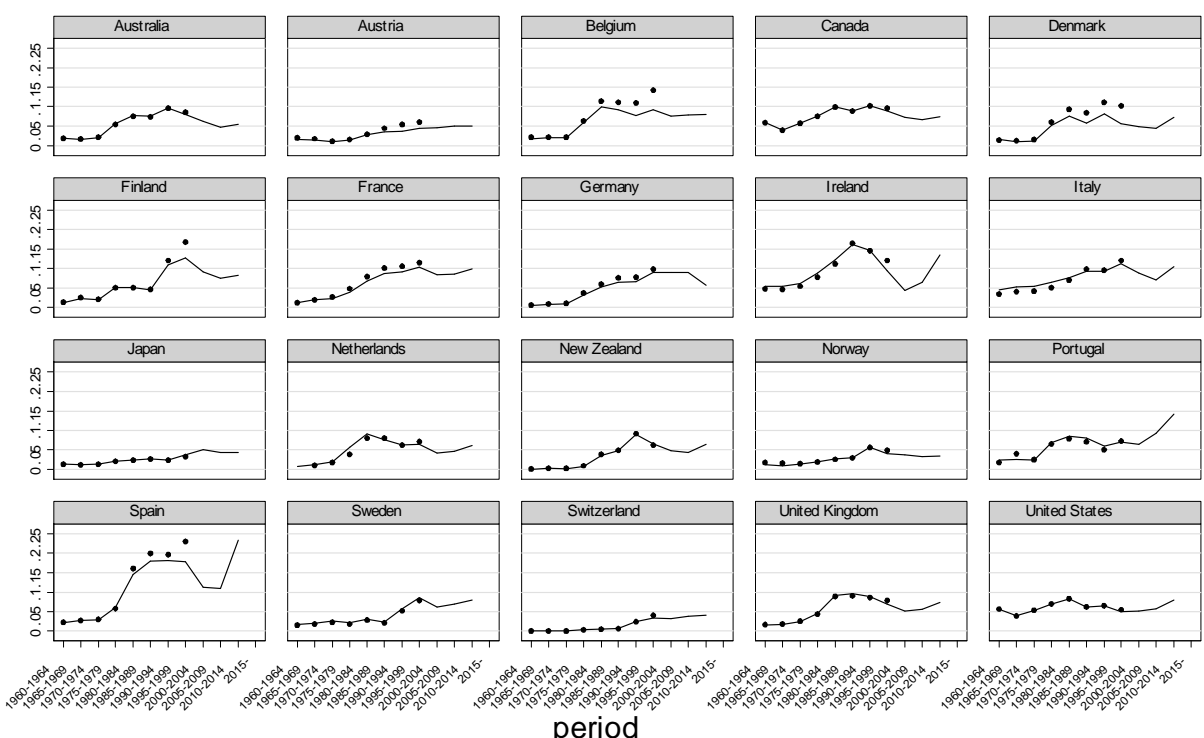

period

- Unemployment rate, BW

Unemployment rate, AMECO

Graphs by cn

For the other variables shown and documented below the AMECO data are used as explanatory variables for the BW variables in linear regressions, including country dummies to try and control for possible definition 
differences and data revisions, whenever the samples overlap sufficiently. Using the estimated coefficients to predict the indicators results in series that are always driven by the most recent data and weigh them in a way meant to replicate and extend the BW variables. The resulting series is not as precisely defined as the ready-made series available for shorter periods in AMECO and/or in the BSDB, but these and especially the latter do not always appear as believable as one would like in the figures below.

\section{Time-varying institutions}

The BW labor tax wedge is the average of 1983-88 and 1989-94 values from the Nickell (1997) database, which include consumption taxes. The first imputation step regresses the BW series on that available for 1979-2004 from OECD Taxing Wages 2007 (odd years 1979-93, not for Australia; annually 1993-2004), defined in terms of income taxes and contributions for manual workers in manufacturing at average full-time wages. The second imputation step uses a current OECD labor tax wedge series, which starts in 2000 and refers to both manual and non-manual workers in a range of industries, for "Single person at $100 \%$ of average earnings, no child" .

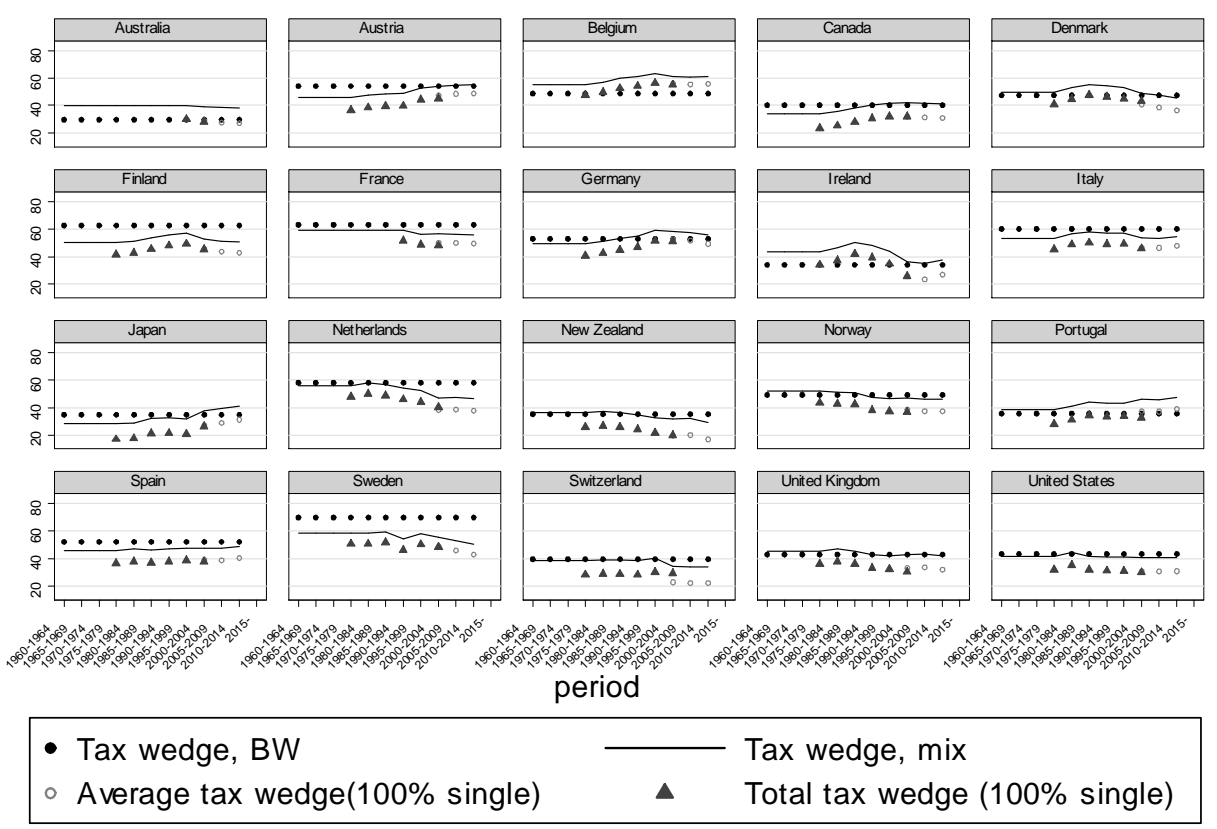

Graphs by cn

For employment protection legislation, the predicted indicator is the BW newep time-varying index, and the recent predictors are the OECD Version 1 (1985-2013) indicators of regular and temporary employment protection stringency. 

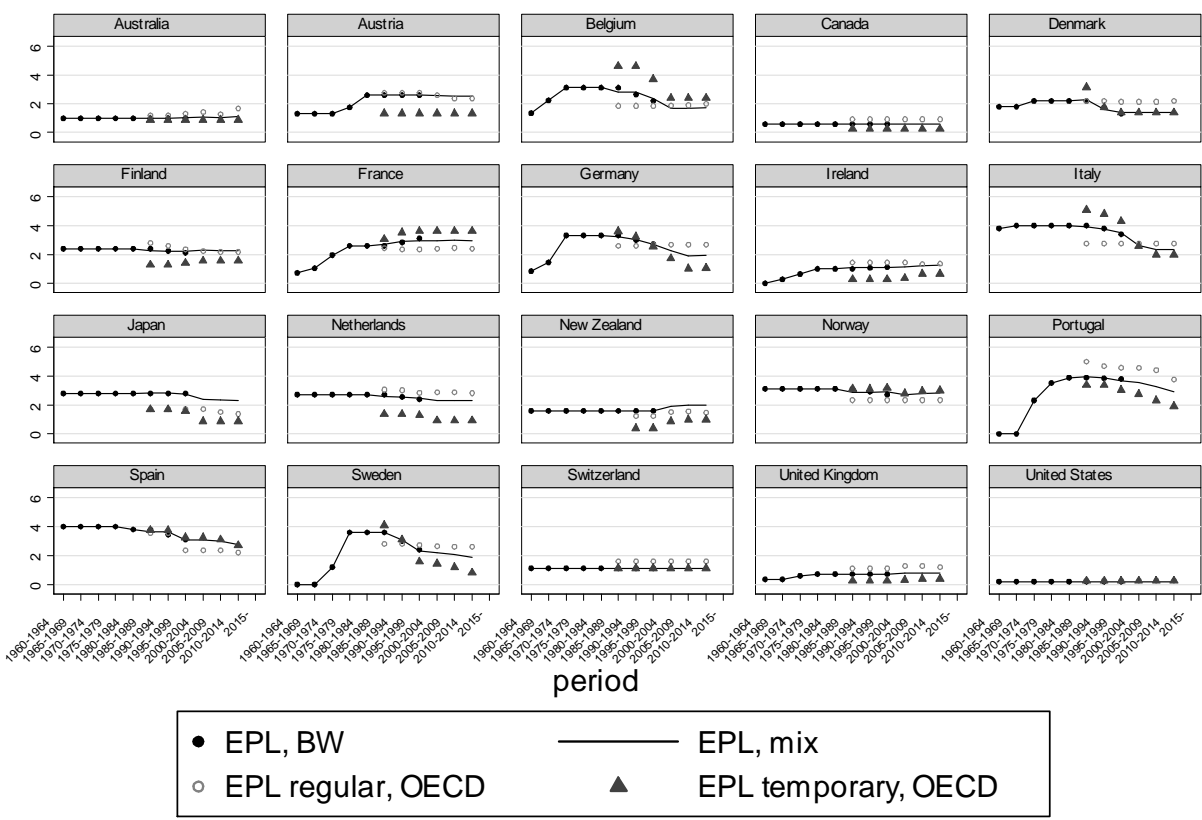

Graphs by cn

Union density data are available from the OECD, from 1960 to 2014 for most countries. Around 1990 the observations are very close to the constant value drawn by BW from the Nickell (1997) database. Missing observations for New Zealand (before 1970), Portugal (before 1978), Spain (before 1980) are filled-in with the earliest available data point.
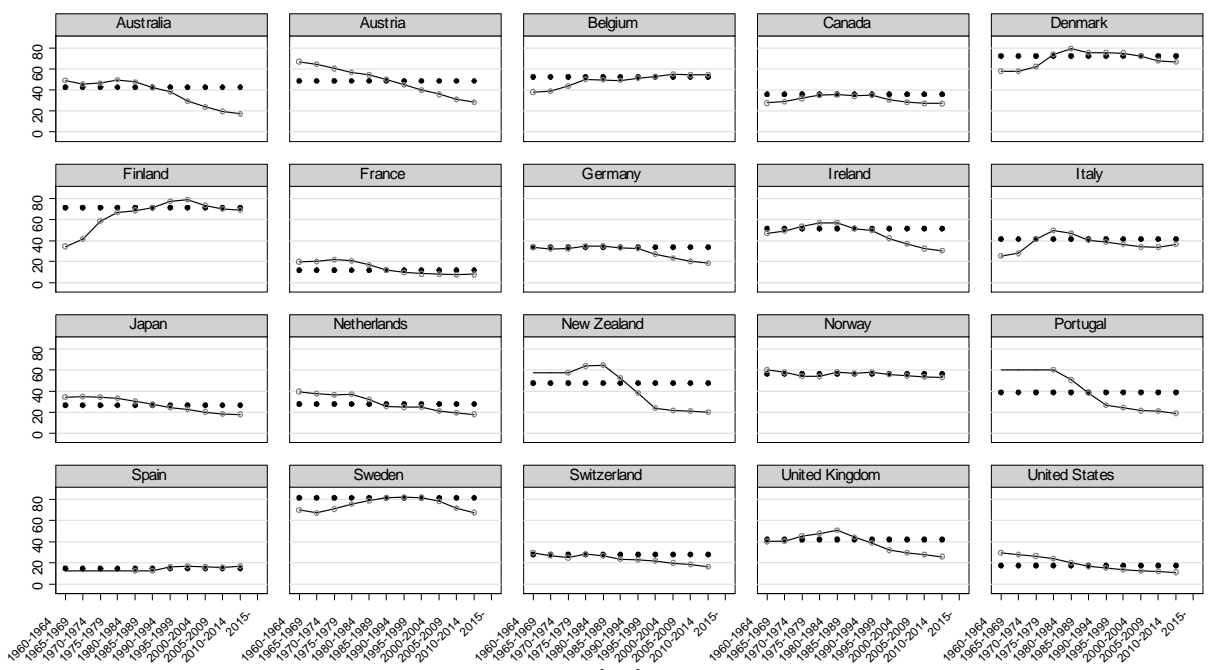

period
- Union density, BW
Union density, mix
$\circ$ Union density

Graphs by cn 
For unemployment insurance replacement rates, imputation needs to proceed in two steps. In the first, the average of the two BW time-varying replacement rate measures (for the initial year and for the ensuing 4 years) is predicted by linear regression on the OECD summary measure of gross benefit entitlements (available for odd-numbered years in 1961-2005) and country dummies. The fit is excellent. The second step regresses the predicted value of the first regression on two series of net unemployment insurance replacement rate series made available since 2001 by the OECD: the unweighted averages across earning levels and family types of initial replacement rates and of the average replacement rates over 5 years. Since the raw gross and net series data series are both available only for 2001, 2003, and 2005, this regression can be run over only two of the estimation sample's 5-year periods. Extrapolating its predictions beyond 2005 makes it possible to exploit the time variation detected by the currently available series over the most recent crisis periods.
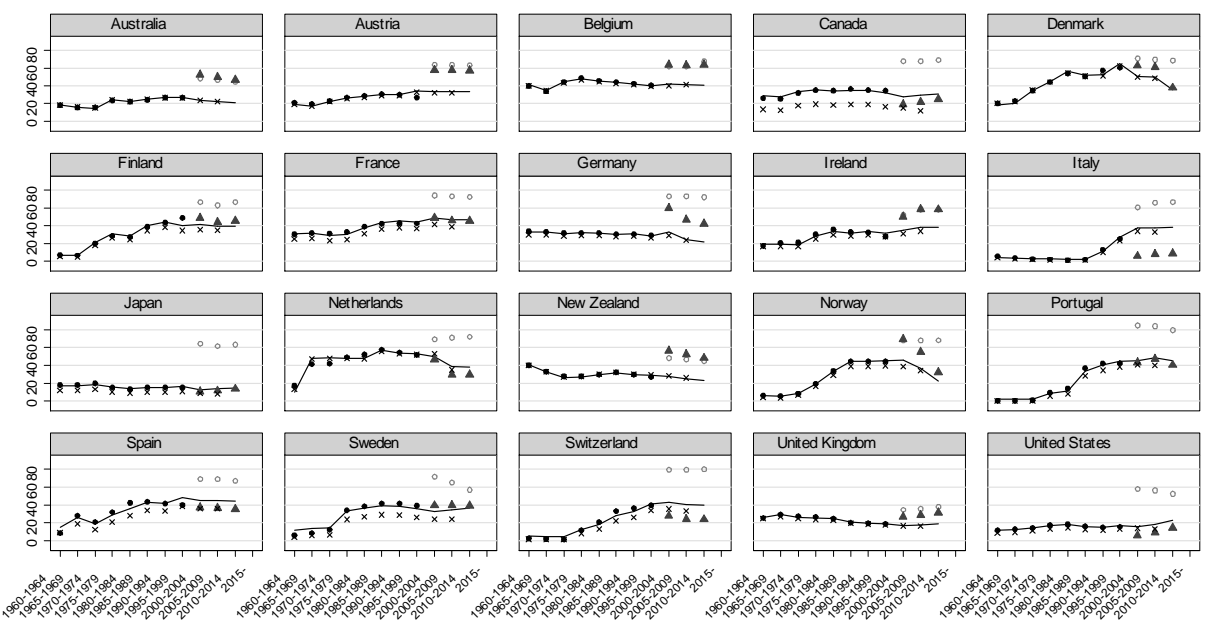

\section{period}
- UI repl rate, avg BW
UI repl rate, mix
- UI repl rate initial, OECD
$\times$ UI summary gross entlt, OECD
$\Delta \quad$ Ul repl rate 5 years avg, OECD

Graphs by cn 


\section{Shocks}

The real interest rate is from AMECO, where it is not available for Australia and New Zealand: for these countries, it is the long-term interest rate available from the OECD since 1970, deflated with the yearly log growth of the AMECO GDP deflator.
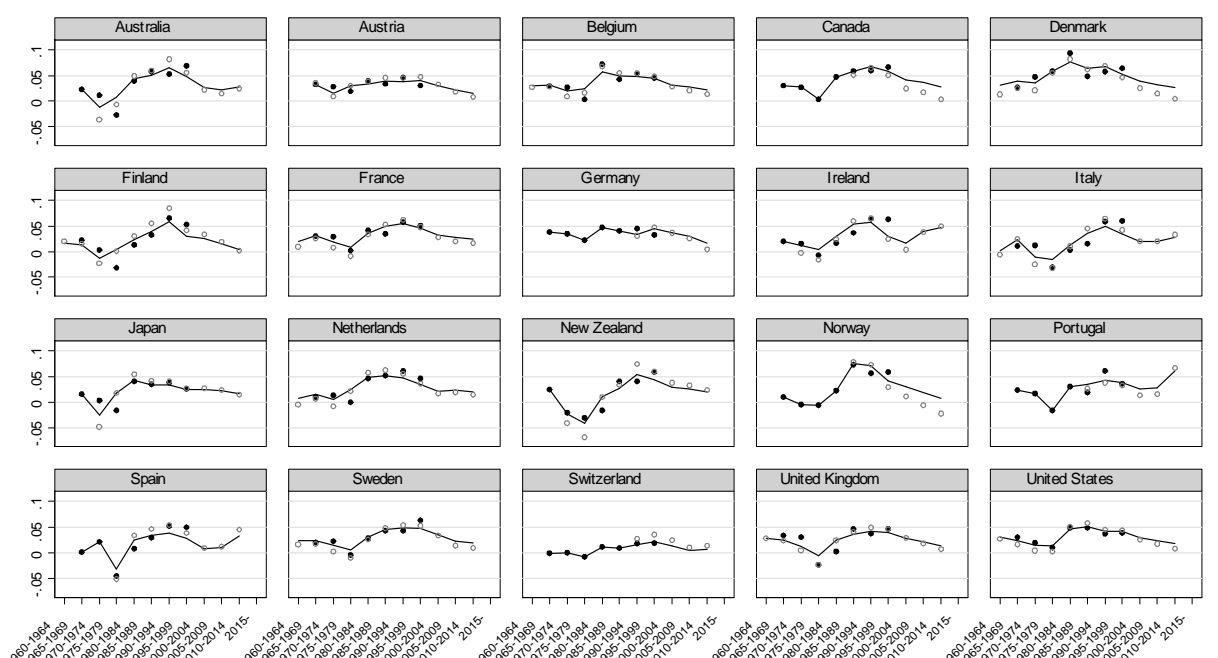

period

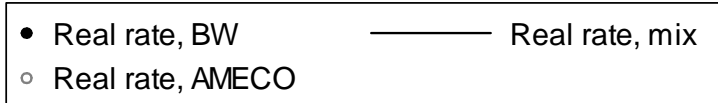

Graphs by cn

BW define the TFP gap as the deviation from country averages of total factor productivity growth, computed from the BSDB output, capital, employment and wage data, normalized by the labor share to express it in labor-augmenting terms. The updated dataset's spliced or "mix "series is the prediction of that BW variable by country dummies and the logarithmic first difference of the AMECO databases total economy factor productivity series. The latter is in most cases available since the early 1960s (with only 3 or 4 observations in the 1960-65 period). Normalizing it by the AMECO labor share measure has no effect on the prediction. Before 1987 for New Zealand and before 1992 for Switzerland total factor productivity is not available in AMECO: the missing observations for these countries are replaced by the corresponding BW data (which appear very noisy in New Zealand). 


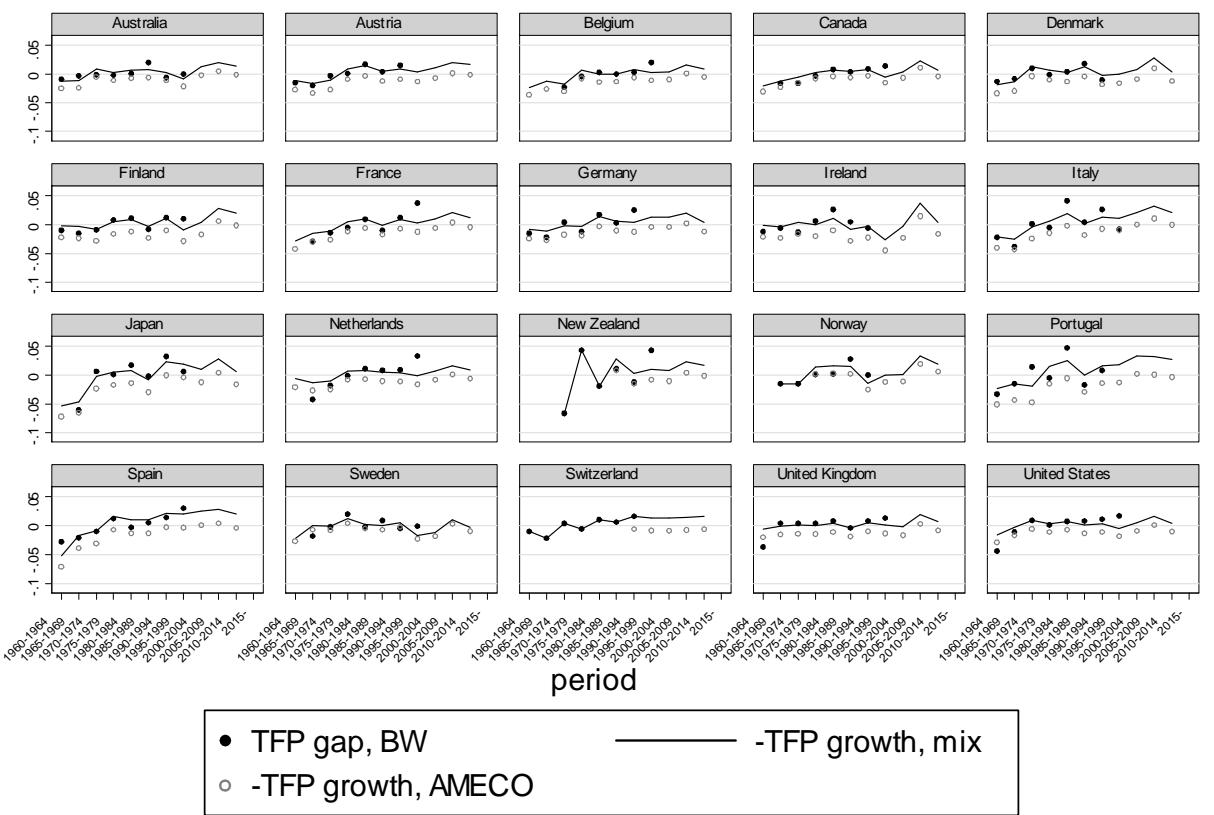

Graphs by cn

Updating the BW labor demand shock requires a more intricate set of computations on AMECO data. Subtracting from the log of "Real compensation per employee, deflator GDP: total economy" (missing for New Zealand and Switzerland before 1991) the log of the ratio of "Total factor productivity: total economy" to "Adjusted wage share: total economy: as percentage of GDP at current prices" (also missing for the same countries and periods) yields BW's adjusted (by labor efficiency) log wage indicator, wadj. Adding labor efficiency to the log of "Employment, persons: all domestic industries (National accounts)" proxies BW's adjusted employment indicator, nadj. The negative of the log of the adjusted labor share, -wadj-nadj plus the log of real GDP (not mentioned in BW's web data appendix, but correctly included when preparing the data made available), corresponds to BW's $1 \mathrm{~d} 0$ variable. Using AMECO data this is identical, or very close in some countries, to the negative log of the AMECO adjusted wage share of GDP. Following BW the AMECO updated labor demand shock uses yearly moving averages of adjusted wages, with weight 0.8 on the current year and 0.2 on the previous year (this makes no difference to the results, which are essentially identical when the contemporaneous labor share), takes 5-year averages, and normalizes the result to zero in 1970 (or the later period when data become available for New Zealand and Switzerland). The "mix" series shown in the figure here and used in the regressions simply splices the BW data to the AMECO series, normalizing the latter to have the same mean over the last two (just one for New Zealand and Switzerland) 5-year periods of the BW data set. The OECD Business Sector indicator behaves very differently from its AMECO total economy counterpart in some countries (such as Portugal, where the "revolution" has completely different and much less drastic implications in AMECO data). However using AMECO observations for the earlier period does not make much of a difference in regressions. 

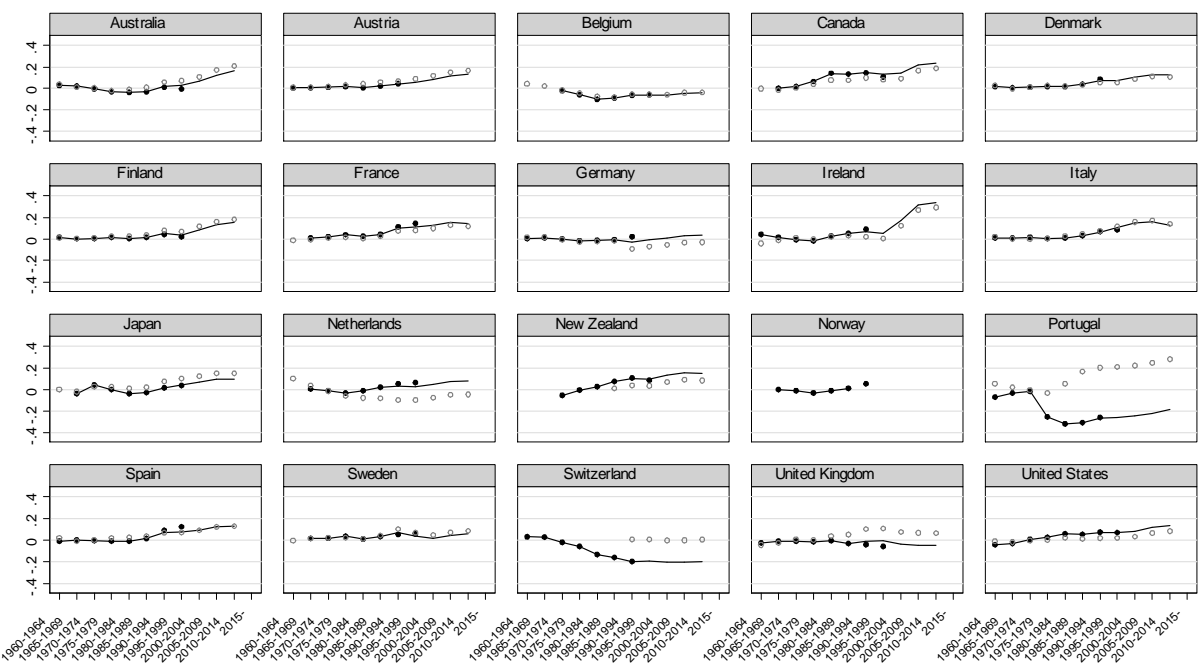

United Kingdom
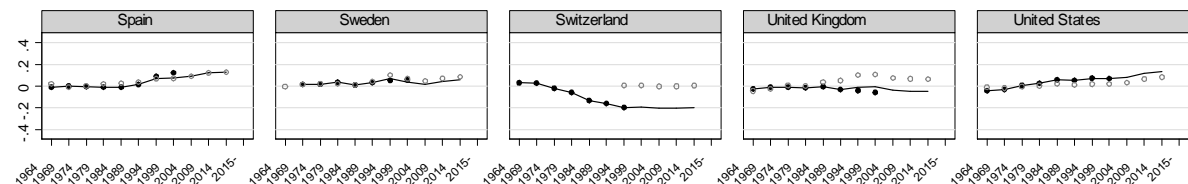

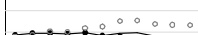

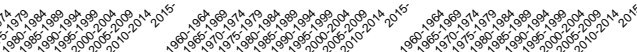

period

- LD shock, BW

LD shock, mix

- LD shock, AMECO

Graphs by cn 